\title{
ASSESSMENT OF THE MEXICAN EAGLE FORD SHALE OIL AND GAS RESOURCES
}

\author{
A Thesis \\ by \\ CARLOS ARMANDO MORALES VELASCO
}

\author{
Submitted to the Office of Graduate Studies of \\ Texas A\&M University \\ in partial fulfillment of the requirements for the degree of \\ MASTER OF SCIENCE
}

Chair of Committee, Duane McVay

Co-Chair of Committee, John Lee

Committee Member, Yuefeng Sun

Head of Department, A. Daniel Hill

August 2013

Major Subject: Petroleum Engineering

Copyright 2013Carlos Armando Morales Velasco 


\begin{abstract}
According to the 2011 Energy Information Agency (EIA) global assessment, Mexico ranks 4th in shale gas resources. The Eagle Ford shale is the formation with the greatest expectation in Mexico given the success it has had in the US and its liquids-rich zone. Accurate estimation of the resource size and future production, as well as the uncertainties associated with them, is critical for the decision-making process of developing shale oil and gas resources.
\end{abstract}

The complexity of the shale reservoirs and high variability in its properties generate large uncertainties in the long-term production and recovery factors of these plays. Another source of uncertainty is the limited production history. Given all these uncertainties, a probabilistic decline-curve analysis approach was chosen for this study, given that it is relatively simple, it enables performing a play-wide assessment with available production data and, more importantly, it quantifies the uncertainty in the resource size.

Analog areas in the US Eagle Ford shale were defined based on available geologic information in both the US and Mexico. The Duong model coupled with a Markov Chain Monte Carlo (MCMC) methodology was used to analyze and forecast production of wells located in the previously defined analog sectors in the US Eagle Ford shale. By combining the results of individual-well analyses, a type curve and estimated ultimate 
recovery (EUR) distribution for each of the defined analog sectors was obtained. These distributions were combined with well-spacing assumptions and sector areas to generate the prospective-resources estimates. Similar probabilistic decline-curve-analysis methodology was used to estimate the reserves and contingent resources of existing wells.

As of March 2013, the total prospective resources (P90-P50-P10) for the Eagle Ford shale in Mexico (MX-EFS) are estimated to be 527-1,139-7,268 MMSTB of oil and 1737-217 TSCF of gas. To my knowledge, this is the first oil estimate published for this formation in Mexico. The most attractive sectors based on total estimated resources as well as individual-well type curves are located in the southeast of the Burgos Basin and east-west of the Sabinas basin. Because there has been very little development to date, estimates for reserves and contingent resources are much lower than those for prospective resources. Estimated reserves associated with existing wells and corresponding offset well locations are 18,375-34,722-59,667 MMSCF for gas and zero for oil. Estimated contingent resources are 14-64-228 MSTB of oil and 8,526-13,32725,983MMSCF of gas. The results of this work should provide a more reliable assessment of the size and uncertainties of the resources in the Mexican Eagle Ford shale than previous estimates obtained with less objective methodologies. 


\section{DEDICATION}

This thesis is dedicated to my fiancée Gaby, for her love and support to pursue my studies; to my father, for his guidance and for being an example of excellence, perseverance, and commitment to the petroleum industry; to my mother, for all the support and time she dedicated to my education during my childhood; and to my brother and sister, for their support in all my endeavors. 


\section{ACKNOWLEDGEMENTS}

I would like to thank Dr. Duane McVay and Dr. John W. Lee for serving as chair and co-chair of my committee, for guiding this work and for their commitment to our education. I would also like to thank Dr. Yuefeng Sun for being part of my committee and Dr. Juan Carlos Laya for serving as a substitute in my thesis defense.

My special thanks to Petróleos Mexicanos for providing me information that allowed the realization of this thesis; in particular to the Burgos asset team: Placido Gerardo Reyes Reza, Jorge Gallardo, Alberto Marino, Ramiro Fernandez, Daniel Olivares, Edgar Reyes, Edgar Silva and Jesus Luces who took the time to meet with me. I also want to recognize the Exploration division who developed the geologic information for the area.

I also want to extend my gratitude to Mexico's Science and Technology Council for funding my studies.

Last but not least I also want to thank Xinglai Gong for his help during my research; and Raul Gonzalez for contributing to the development of the Probabilistic Decline Curve Analysis package used in this thesis. 


\section{TABLE OF CONTENTS}

Page

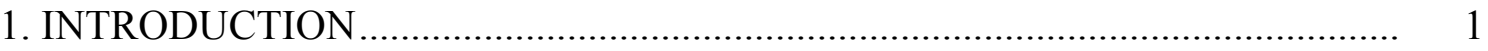

1.1. Global context and problem statement .................................................. 1

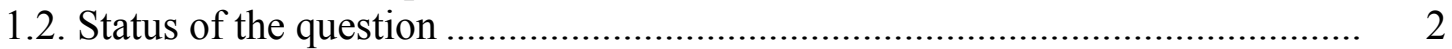

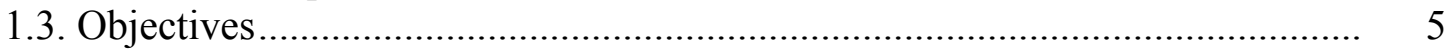

1.4. General approach................................................................................. 5

2. GEOLOGY AND RESERVOIR CHARACTERIZATION .................................. 7

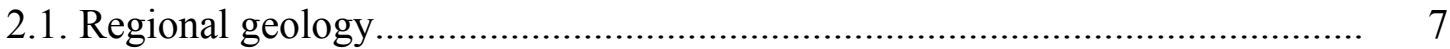

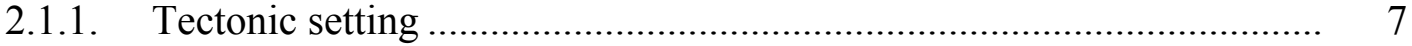

2.1.2. Structural setting.......................................................................... 8

2.1.3. Regional stratigraphy and depositional environments ........................ 9

2.1.4. Petroleum system history and description.......................................... 11

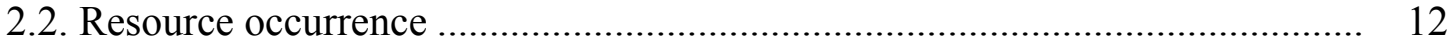

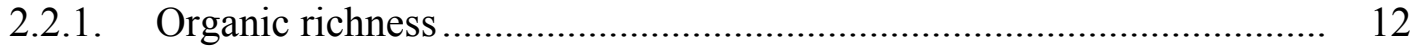

2.2.2. Thermal maturity and kerogen types ............................................ 13

2.3. Area prioritization ......................................................................... 13

3. PROBABILISTIC DECLINE-CURVE ANALYSIS REVIEW ......................... 17

3.1. Probabilistic decline-curve analysis (PDCA) models ................................ 17

3.1.1. Decline-curve models for shales ................................................. 17

3.1.2. Probabilistic methodologies ......................................................... 18

3.2. Description of selected PDCA methodology ........................................... 21

4. PROSPECTIVE RESOURCES ............................................................... 24

4.1. Identification of analog sub-areas in the US-EFS ..................................... 24

4.2. Generate probabilistic type curves for each analog sector ........................... 30

4.2.1. Prior distribution of cumulative production after 20 years (N240)...... 31

4.2.2. Minimum decline assumptions..................................................... 32

4.2.3. Gas/oil ratio (GOR) assumptions ............................................... 33

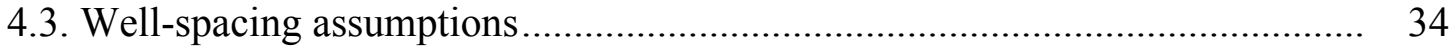

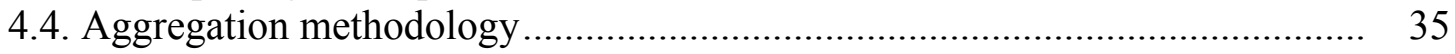

4.5. Results and discussion........................................................................ 36

5. RESERVES AND CONTINGENT RESOURCES .......................................... 42 
5.1. Applicable wells 42

5.2. Economic evaluation ........................................................................ 43

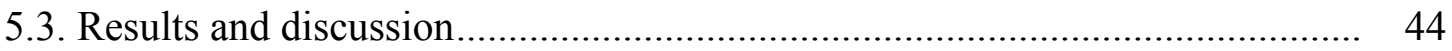

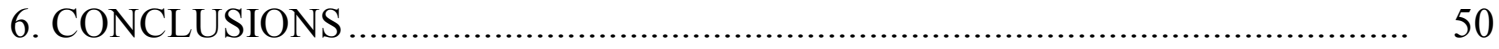

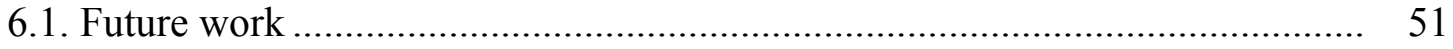

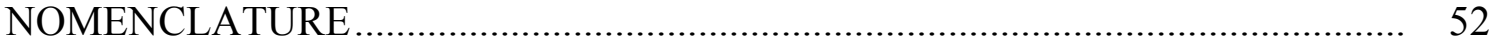

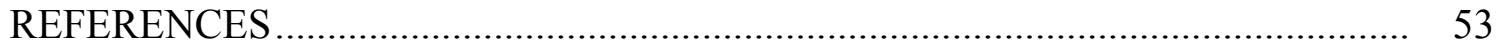




\section{LIST OF FIGURES}

Page

Fig. 1 MX-EFS area prioritization and resulting sectors ............................... 15

Fig. 2 Production data analysis and forecast methodology for individual wells and sector type curves .................................................................. 23

Fig. 3 Effects of depth and TOC on cumulative oil and gas production ............. 26

Fig. 4 Effects of thickness and thermal maturity on cumulative oil and gas

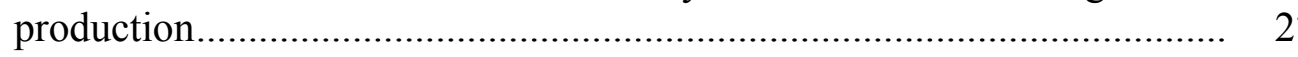

Fig. 5 Defined US-EFS analog sectors .................................................... 30

Fig. 6 Oil and gas production type curves for the North Mature US-EFS sector

Fig. 7 Oil and gas production type curves for the South Mature US-EFS sector with different fluid type assumptions ................................................. 38

Fig. 8 Oil and gas production type curves for the South Overmature and South Thick-Mature US-EFS sectors

Fig. 9 Production forecast for well A

Fig. 10 Production forecast for well B

Fig. 11 Gas volumes distribution for 6 offset wells to well A........................... 46

Fig. 12 Gas volumes distribution for 6 offset wells to well B .......................... 47 


\section{LIST OF TABLES}

Page

Table 1 Observed facies throughout the Eagle Ford shale in Mexico .................. 11

Table 2 Minimum cut-off values for area prioritization .................................. 14

Table 3 Characteristics of each of the defined sectors in MX-EFS .................... 16

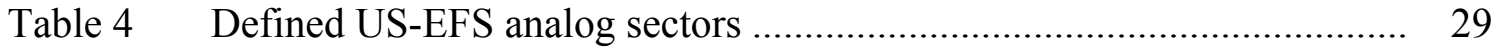

Table 5 Equivalent regions from Gong (2013) and prior N240 distributions....... 32

Table 6 Selected well spacing for each MX-EFS sector................................. 35

Table 7 EUR at 240 months distributions for each US-EFS analog sector .......... 36

Table $8 \quad$ Prospective resources for the MX-EFS by sector .............................. 40

Table $9 \quad$ Wells drilled and completed in the MX-EFS as of March $2013 \ldots \ldots \ldots \ldots . . . . \quad 42$

Table 10 Economic assumptions to determine offset wells resource classification 44

Table 11 Forecasted EUR distribution for each existing producing well in MMSCF .................................................................................. 44

Table 12 Economic evaluation for Well A type curve applicable to offset wells ... 48

Table 13 Economic evaluation for Well B type curve applicable to offset wells.... 48

Table 14 Individual and total reserves for applicable MX-EFS wells.................. 49

Table 15 Individual and total contingent resources for applicable MX-EFS wells. 49 


\section{INTRODUCTION}

\subsection{Global context and problem statement}

The success of shale plays in North America has triggered interest in finding and exploiting similar plays in other parts of the world. According to EIA (2011b), Mexico ranks 4th in shale gas resources. Although there are several identified shale plays in Mexico, the Eagle Ford shale is the one with the greatest expectation given the success it has had in the US and its liquids-rich zone. Accurate estimation of the resource size and future production, as well as the uncertainty associated with them, is critical for the decision-making process of developing shale resources. Inaccurate estimations and/or underestimation of uncertainty jeopardizes the making of correct decisions during the evaluation, planning and execution of multi-billion-dollar projects. Appropriate energy policies and regulations may also need to be modified depending on the resource size. Accurate assessment of the resources and the related uncertainty can support optimization of all these decisions.

Accurate reserve/resource estimation and production forecasting in shale reservoirs has been a challenge. The complexity of the reservoirs and high variability in its properties generate large uncertainties in these estimates. Most methods commonly used to estimate reserves and resources in conventional reservoirs have encountered numerous challenges or are not appropriate for shale gas and oil reservoirs without modification. Using these methods in shale plays can result in inaccurate and sometimes unrealistic 
reserves estimates and production forecasts, as pointed out by Duong (2010). Another source of uncertainty in estimates of long-term production and recovery factors in these plays is the limited production history. These types of reservoirs have been producing

for only a few years (at most) and completion/stimulation techniques are still evolving. Companies and government agencies in the US have historically underestimated these resources (Dong et al. 2011), which indicates the limitations/deficiencies in the estimation methodologies being used.

The area overlaying the Eagle Ford shale in Mexico has had oil and gas activity since the 1950 's, with many wells penetrating this formation since then. A significant amount of reservoir characterization information has been obtained from these wells. However, given the limited production information, future reservoir performance and its variability is still uncertain. As of March 2012, five wells have been drilled and completed targeting the MX-EFS, with varying results. In contrast, more than 2,400 wells are producing in the US Eagle Ford shale (US-EFS).

\subsection{Status of the question}

As of March 2012, two studies have been done to estimate the resources of the Eagle Ford shale in Mexico. The EIA estimated 21 TCF technically recoverable gas resources in the US-EFS (EIA 2011a), and 498 TCF for the MX-EFS (EIA 2011b). In both estimates the methodology involved subjective recovery and risk factors that were 
applied to in-place estimates, and it was recognized that the technically recoverable gas estimates have significant uncertainty, which was not quantified.

In November 2011, Petróleos Mexicanos (PEMEX) estimated prospective gas resources in the different plays. For the Upper Cretaceous (which includes the Eagle Ford shale) the estimates were 54-106-171 TCF (P90-P50-P10). For the Eagle Ford and Agua Nueva shales combined resources were estimated to be 27-87 TCF (P90-P10) (PEMEX 2011).

An assessment of the Eagle Ford shale oil and gas resources in the US is being done by the Crisman Institute for Petroleum Research at Texas A\&M University. This assessment employs a probabilistic methodology to quantify the uncertainty in the resources estimates.

Different methodologies have been used to estimate reserves/resources and forecast production depending on the information available and the nature of the reservoir: material balance, analogy, volumetric analysis, reservoir simulation, and decline-curve analysis (Baihly et al. 2010). However, some of these methodologies have clear disadvantages and limitations when applied to shale reservoirs:

- Material Balance. This requires accurate average reservoir pressure data, which is difficult to obtain in shales. Although widely used for gas reservoirs, the fact that the input data are unavailable prevents it from being applied in shales. In the case of oil reservoirs the method can be very complex. 
- Analogs. Given the differences in the petrophysics of shales, the different drilling and completion techniques being used, and the relatively few plays being developed, forecasts by analogy are uncertain. Even within the same plays there have been wells with very different performance.

- Volumetric analysis. This requires recovery factors and drainage areas to estimate reserves. There is still a lot of uncertainty in the recovery factors that can be achieved in shales (both gas and oil) and in the drainage areas of the wells. On top of this, it has been recently published that, although shales can be hundreds of meters in thickness, there is a lot of heterogeneity in the organic content across shale, and hence the productive zones. Also, there is indication that the porosity of shales is of a different nature than conventional reservoirs, and that the hydrocarbon accumulations may be only in the porosity of organic matter (Passey et al. 2010).

- Reservoir simulation. This has been applied to individual shale gas and oil wells, and allows accounting for the effects of the hydraulic fracture and matrix natural fractures (although their role is not yet fully understood) (Chaudhary et al. 2011). Simulation has not been applied field wide, given the limited interaction/effects among wells. Additionally, this method is normally time consuming and expensive.

- Decline-Curve Analysis. This is the most commonly used method to forecast production and estimate reserves in shale plays. Significant improvement has been achieved in this technique with probabilistic methods that provide accurate 
predictions and quantification of uncertainty (Gong et al. 2011). Most of the studies have focused on shale gas, and more research is required to prove the applicability of the techniques to gas condensate and oil production from shales.

It has been 1 to 2 years since previous assessments were done and new production/geologic information in the area enables the refinement of them. One of the previous estimates did not quantify uncertainty, and, to my knowledge, none of them quantified oil resources. This thesis covered these research gaps.

\subsection{Objectives}

The objective of this study was to estimate the oil and gas reserves, as well as contingent and prospective resources, in the Mexican Eagle Ford shale and to quantify the uncertainties in these estimates.

\subsection{General approach}

The SPE Petroleum Resources Management System (PRMS) guide was the reference for the definition of the different resource categories. Throughout the study, the term "area" refers to the gross area of interest that the Eagle Ford shale covers in Mexico, and the term "sector," refers to a smaller area defined within that gross area. This study was broken down into two major workflows given the available information and the considerations each of them required. 
The first workflow focused on estimation of the prospective resources. The production information from the US and the reservoir characterization information from the Mexican side was analyzed and combined to estimate the resources from the Eagle Ford formation in Mexico. The MX-EFS prospective resources were estimated based on the generation of type curves and EUR distributions on analog sectors in the US-EFS.

The second workflow estimated the reserves and contingent resources of the existing wells. As mentioned, only two wells have been producing from the Eagle Ford formation, and 3 more have been drilled with no commercial results. For the producing wells, an estimate of the reserves was calculated with a probabilistic decline-curve model. 


\section{GEOLOGY AND RESERVOIR CHARACTERIZATION}

\subsection{Regional geology}

The Eagle Ford formation extends through the northeastern part of Mexico in the states of Coahuila, Nuevo Leon and Tamaulipas. The area of interest covers 17.8 million acres $\left(72,283 \mathrm{~km}^{2}\right)$. This formation extends through portions of the Maverick, Sabinas and Burgos basins: from the Maverick Basin in the US to the area of Tampico (north to south), and from the Sierra Madre Oriental ridge to the Gulf of Mexico (northwest to southeast).

The region has been exploited for over 6 decades and significant information has been gathered and analyzed to characterize the formation. More than 250 wells have been drilled in the area targeting other formations, and some of these wells showed manifestations of oil and gas presence from the Eagle Ford shale with no commercial production.

\subsubsection{Tectonic setting}

The Sabinas Basin is an intracratonic basin where sediments started depositing towards the end of the Triassic. The main paleo-elements of the basin are the Tamaulipas Peninsula, the Burros-Picachos platform, Coahuila Island and the Sabinas basin. The region went through a continent-continent collision which formed Pangea during the late Paleozoic. A rifting phase occurred from the late Triassic through the Middle Jurassic; a 
fault system developed as well during this time, allowing the formation of trenches where sediments accumulated. During the late Jurassic the Gulf of Mexico oceanic crust formed, while tectonic and thermal subsidence affected the region during the late Jurassic and the Cretaceous. The passive margin phase finished with the start of the Laramide Orogeny, which caused the formation of the Sierra Madre Oriental range and the development of foreland basins (including Sabinas and Burgos basins)(Cabrera et al. 2010b). The region is currently under compressional tectonic stresses.

The Burgos Basin underwent the same major tectonic events. From the Late Jurassic to the end of the Mesozoic the area was an extensive continental shelf. After the Laramide orogeny event, during the Cenozoic, the area went through sea transgression. Extensional faults were also formed in this period, resulting from tectonic up-rise and sedimentation (Cabrera et al. 2010a).

\subsubsection{Structural setting}

During the Cenomanian-Turonian, the Maverick basin was defined by the San Marcos arch in the US and the Salado Arch in Mexico, which also influenced the Sabinas basin. The Eagle Ford shale formation is affected by these two paleo-elements, as it gets thinner towards these paleo-elements and thicker as it gets further.

Towards the southeast, the Eagle Ford shale is highly influenced by the edge of the Albian platform. This also marks the start of Agua Nueva formation, which formed in a 
deeper depositional environment (Tellez-Aviles et al. 2011). For the purpose of this study the Eagle Ford shale and the Agua Nueva formation are referred to as Eagle Ford.

The Salado Arch runs southeast with a bifurcation on its southern edge. The smaller bifurcation is an extensive anticline with the Maverick basin to the east and the Sabinas basin to the west. Towards the Sabinas basin the structure is a syncline running southeastward. The basin is affected by inverse faults, which originated elongated synclines in the same direction.

In the Burgos basin area, there is an extensive and steep monocline, deepening considerably towards the east and shifting directions towards the south. Depths reach up to $4,500 \mathrm{~m}(14,700 \mathrm{ft})$. This part is closely bounded by the Aptian shelf margin to the north.

\subsubsection{Regional stratigraphy and depositional environments}

Deposition in the Sabinas Basin started in the late Triassic with the erosion of the paleoelements and volcanic rocks created during the rifting process. Evaporites were deposited during the Callovian, and sea transgression caused the deposition of carbonates in the late Jurassic. During the Berriasian, a strong flux of conglomerates, sandstones and carbonate shales (i.e. La Casita formation) deposited. Cycles of sea transgression and regression caused the deposition of carbonates and shales until the end of the Cretaceous. It was during the late Cenomanian that the Eagle Ford shale and 
Austin Chalk were deposited. The sedimentation changed drastically during the Campanian and Maastrichtian, resulting from the tectonic movement and uplift towards the north/west, causing the erosion of the uplifted region and the sedimentation of clastics.

As in the US, the MX-EFS shale can be divided into lower and upper units. The depositional environment for both units corresponds to an open continental shelf influenced by a deltaic fluvial system (Tellez-Aviles et al. 2011).

In general, the lower unit is transgressive organic rich and has well laminated shales, while the upper unit is regressive with thin laminated shales, carbonate sand siltstones (Araujo et al. 2012). Different facies are observed in each of the units throughout the area of interest (Table 1). 
Table 1- Observed facies throughout the Eagle Ford shale in Mexico

\begin{tabular}{|c|c|c|}
\hline Facies & Lower Unit & Upper Unit \\
\hline $\begin{array}{l}\text { Calcareous- } \\
\text { Carbonaceous } \\
\text { Shale }\end{array}$ & $\begin{array}{l}\text { Description: Laminated, abundant } \\
\text { plankton fossils, abundant pyrite, gives } \\
\text { a high gamma-ray reading, brittle, } \\
\text { black. Interbedded with thin layers of } \\
\text { wackestone-packstone clay of dark } \\
\text { gray to black color } \\
\text { Location: North and north-west part of } \\
\text { the area } \\
\text { Thickness: } 98-246 \mathrm{ft},(30-75 \mathrm{~m})\end{array}$ & Not present \\
\hline $\begin{array}{l}\text { Shaly Limestone } \\
\text { / Calcareous- } \\
\text { Carbonaceous } \\
\text { Shale }\end{array}$ & $\begin{array}{l}\text { Description: Mudstone to packstone } \\
\text { limestone, with thin to medium layers, } \\
\text { dark gray to black color, few micro } \\
\text { fractures sealed with calcite. } \\
\text { Interbedded with intervals of thin } \\
\text { laminated, black, calcareous- } \\
\text { carbonaceous shale } \\
\text { Location: Center-north and a small } \\
\text { region in the southeastern part of the } \\
\text { area } \\
\text { Thickness: } 85-164 \mathrm{ft},(26-50 \mathrm{~m})\end{array}$ & $\begin{array}{l}\text { Description: Dense and compact limestone } \\
\text { with thin layers, dark gray to black color } \\
\text { with some beds of light gray-gray color, } \\
\text { abundant plankton fossils, few micro } \\
\text { fractures sealed with calcite. Interbedded } \\
\text { with organic rich calcareous-carbonaceous } \\
\text { shale } \\
\text { Location: North and north-west part of the } \\
\text { area and a region in the south } \\
\text { Thickness: } 656-1312 \mathrm{ft},(200-400 \mathrm{~m}) \text { in the } \\
\text { north and } 196-426 \mathrm{ft}(60-130 \mathrm{~m}) \text { in the south }\end{array}$ \\
\hline $\begin{array}{l}\text { Limestone / } \\
\text { Shaly limestone }\end{array}$ & $\begin{array}{l}\text { Description: Mudstone to packstone } \\
\text { limestone, with thin to medium layers, } \\
\text { dark gray to black color with some } \\
\text { greenish beds. Interbedded with } \\
\text { intervals of thin laminated, black, } \\
\text { fissile, shaly limestone } \\
\text { Location: South part of the area } \\
\text { Thickness:98-196 ft, }(30-60 \mathrm{~m})\end{array}$ & $\begin{array}{l}\text { Description: Very similar to lower unit } \\
\text { facie, with thick to medium layers, light to } \\
\text { dark gray with some greenish laminae. } \\
\text { Interbedded with thin intervals of fissile, } \\
\text { dark gray to black, carbonaceous shales. In } \\
\text { the south central part thin layers of clay } \\
\text { sandstone and fractures are present } \\
\text { Location: Central part of the area. Covers } 3 / 4 \\
\text { of the area } \\
\text { Thickness: } 196-656 \mathrm{ft},(60-200 \mathrm{~m})\end{array}$ \\
\hline
\end{tabular}

\subsubsection{Petroleum system history and description}

With the successful first well targeting the Eagle Ford Shale in early 2011, an

"unconventional" petroleum system could be considered known, and this shale would be

both the source, reservoir and seal rock, also acting as a trap through the high capillary 
pressure. It is estimated that the Eagle Ford shale went into the hydrocarbon generation window 68 million years ago; however, it was uplifted by the Laramide orogeny event 48-33 million years ago, causing it to go outside this window. It is still hypothetical how much the Eagle Ford charged other reservoirs.

\subsection{Resource occurrence}

Samples and analyses of a subset of 125 wells in the area enabled the characterization of the resource occurrence in both units of the Eagle Ford Shale. These wells penetrated the Eagle Ford shale targeting deeper formations.

\subsubsection{Organic richness}

For the lower unit, the area with the highest total organic content (TOC) values is near Piedras Negras, Coahuila, ranging from $2.0 \%$ to more than $7.0 \%$. The areas with the highest organic content correspond to the areas of the carbonate platform of the Albian, which probably provided the depositional conditions that allowed a high population of microorganisms that deposited after dying in an euxinic environment. Although the TOC decreases slightly toward the south and southwest of this area, it is still considered verygood, ranging from 2.0 to $4.0 \%$ TOC. To the east, the TOC decreases in most parts to 0 to $2.0 \%$ TOC, considered poor to good.

The Upper unit presents slightly lower values, but with a very similar distribution in the area (Tellez-Aviles et al. 2011). The highest values are found in the northern part of the 
area with an average of $4.0 \%$ TOC. In the Platform of Tamaulipas paleo-area values of $2.0 \%$ are found, while further to the south/southeast of the area values drop to $0.8 \%$.

\subsubsection{Thermal maturity and kerogen types}

The maturity of the source rock was obtained through pyrolysis analysis. Two areas were interpreted as over-mature: the northern-west portion of the Sabinas basin and the area next to the US border near Laredo. An extensive zone running all across the center limit of the play in the southeast direction was interpreted as mature. Another area considered mature was found in the center-west of the Sabinas basin area. The remaining area was considered to be immature (Tellez-Aviles et al. 2011). The kerogen identified in the source rock is a mix of type II and III, indicating the source rock is both oil and gas prone, as observed in the US side (Cabrera et al. 2010b).

\subsection{Area prioritization}

Based on geologic and resource occurrence characteristics, the area was analyzed and divided into the most prospective sectors. Minimum cutoffs values were established (Table 2) and maps were overlaid to come up with the final prospective sectors. The formation thickness and lithofacies were also considered for the area prioritization, but no minimum values were established for these two variables. Based on this, PEMEX defined 12 prospective sectors. This prioritization was done based on the Lower Eagle Ford shale, where most of the production has come from in US-EFS (Tellez-Aviles et al. 2011). 
Table 2- Minimum cut-off values for area prioritization

\begin{tabular}{|c|c|}
\hline Variable & Cut-off value \\
\hline Depth & $2,300 \mathrm{ft}(700 \mathrm{~m})$ \\
\hline TOC & $1 \%$ \\
\hline Maturity & Mature \\
\hline
\end{tabular}

For the purpose of this thesis, sectors were grouped based on similarities and the available information of analog sectors in US-EFS (which is explained later in the text). Sector G was not considered, given that it was not classified as shale and hence would not be appropriate to compare it with any area of the US-EFS. The location of each of the defined sectors is shown in Fig. 1 and a description of each of them is shown in

\section{Table 3.}




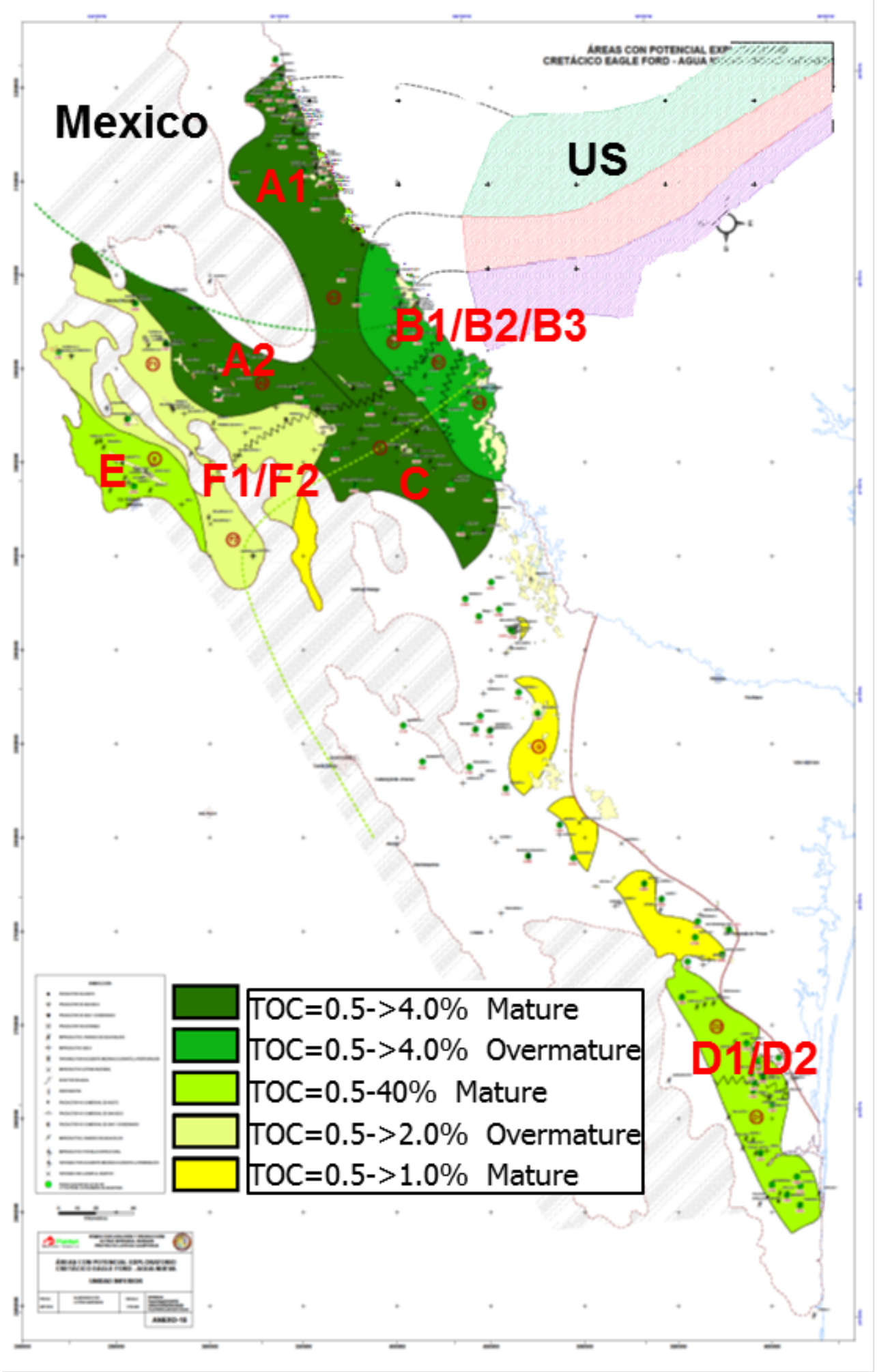

Fig. 1- MX-EFS area prioritization and resulting sectors 
Table 3- Characteristics of each of the defined sectors in MX-EFS

\begin{tabular}{|c|c|c|c|c|c|c|c|}
\hline Variable & A1 & $\mathrm{A2}$ & B1 / B2 / B3 & $\mathrm{C}$ & D1 / D2 & $\mathbf{E}$ & F1/F2 \\
\hline Location & $\begin{array}{l}\text { Northern part of } \\
\text { the area, to the } \\
\text { east of the Salado } \\
\text { Arch }\end{array}$ & $\begin{array}{l}\text { Northern part of } \\
\text { the area, to the } \\
\text { west of the } \\
\text { Salado Arch }\end{array}$ & $\begin{array}{l}\text { Northeast part of } \\
\text { the area. Next to } \\
\text { the border with } \\
\text { US }\end{array}$ & $\begin{array}{l}\text { Southwest of } \\
\text { sectors } \mathrm{A} 1 / \mathrm{A} 2, \\
\text { and south of } \\
\text { sectors B1/B2/B3 }\end{array}$ & $\begin{array}{l}\text { Southernmost } \\
\text { part of the area. }\end{array}$ & $\begin{array}{l}\text { Central-West } \\
\text { part of the area. } \\
\text { Central part of } \\
\text { the Sabinas } \\
\text { Basin }\end{array}$ & $\begin{array}{l}\text { Between } \\
\text { sectors A2, E } \\
\text { and C. In the } \\
\text { north of the } \\
\text { Sabinas Basin }\end{array}$ \\
\hline Area & $\begin{array}{l}1,491,281 \text { acre } \\
\left(6,035 \mathrm{~km}^{2}\right)\end{array}$ & $\begin{array}{l}878,460 \text { acre } \\
\left(3,555 \mathrm{~km}^{2}\right)\end{array}$ & $\begin{array}{l}1,029,935 \text { acre } \\
\left(4,168 \mathrm{~km}^{2}\right)\end{array}$ & $\begin{array}{l}1,139,897 \text { acre } \\
\left(4,613 \mathrm{~km}^{2}\right)\end{array}$ & $\begin{array}{l}975,819 \text { acre } \\
\left(3,949 \mathrm{~km}^{2}\right) \\
\end{array}$ & $\begin{array}{l}564,142 \text { acre } \\
\left(2,283 \mathrm{~km}^{2}\right)\end{array}$ & $\begin{array}{l}1,680,564 \text { acre } \\
\left(6,801 \mathrm{~km}^{2}\right)\end{array}$ \\
\hline TOC & $\begin{array}{l}\text { Excellent. } \\
\text { Ranging from } \\
2.35 \text { to } 7.49 \%\end{array}$ & $\begin{array}{l}\text { Very good. } \\
\text { Ranging from } \\
2.46 \text { to } 3.97 \%\end{array}$ & $\begin{array}{l}\text { Good - Very } \\
\text { good. Ranging } \\
\text { from } 1.05 \text { to } \\
4.54 \%\end{array}$ & $\begin{array}{l}\text { Good. Ranging } \\
\text { from } 0.53 \text { to } \\
3.06 \%\end{array}$ & $\begin{array}{l}\text { Good. Ranging } \\
\text { from } 0.76 \text { to } \\
1.95 \%\end{array}$ & $\begin{array}{l}\text { Very good. } \\
\text { Ranging from } \\
1.9 \text { to } 2.84 \%\end{array}$ & $\begin{array}{l}\text { Very good. } \\
\text { Ranging from } \\
1.90 \text { to } 3.59 \%\end{array}$ \\
\hline Maturity & $\begin{array}{l}\text { Mature. Tmax } \\
430-460{ }^{\circ} \mathrm{C}\end{array}$ & $\begin{array}{l}\text { Mature. Tmax } \\
430-460{ }^{\circ} \mathrm{C}\end{array}$ & $\begin{array}{l}\text { Overmature. } \\
\text { Tmax }>460^{\circ} \mathrm{C}\end{array}$ & $\begin{array}{l}\text { Mature. Tmax } \\
430-460{ }^{\circ} \mathrm{C}\end{array}$ & $\begin{array}{l}\text { Mature. Tmax } \\
430-460{ }^{\circ} \mathrm{C}\end{array}$ & $\begin{array}{l}\text { Mature. Tmax } \\
430-460{ }^{\circ} \mathrm{C}\end{array}$ & $\begin{array}{l}\text { Overmature. } \\
\text { Tmax }>460^{\circ} \mathrm{C}\end{array}$ \\
\hline Facies & $\begin{array}{l}\text { Calcareous- } \\
\text { Carbonaceaous } \\
\text { Shales / Shaly } \\
\text { limestone }\end{array}$ & $\begin{array}{l}\text { Carbonaceous } \\
\text { shales / shaly } \\
\text { limestone }\end{array}$ & $\begin{array}{l}\text { Calcareous- } \\
\text { Carbonaceaous } \\
\text { Shales / Shaly } \\
\text { limestone / } \\
\text { Limestone }\end{array}$ & $\begin{array}{l}\text { Shaly limestone / } \\
\text { Calcareous- } \\
\text { Carbonaceaous } \\
\text { Shales }\end{array}$ & $\begin{array}{l}\text { Calcareous- } \\
\text { Carbonaceaous } \\
\text { Shales / Shaly } \\
\text { limestone / } \\
\text { Limestone }\end{array}$ & $\begin{array}{l}\text { Calcareous- } \\
\text { Carbonaceaous } \\
\text { Shales / Shaly } \\
\text { limestone }\end{array}$ & $\begin{array}{l}\text { Calcareous- } \\
\text { Carbonaceaous } \\
\text { Shales / Shaly } \\
\text { limestone. }\end{array}$ \\
\hline Thickness & $\begin{array}{l}98-180 \mathrm{ft}(30-55 \\
\mathrm{m})\end{array}$ & $\begin{array}{l}98-180 \mathrm{ft}(30-55 \\
\mathrm{m})\end{array}$ & $\begin{array}{l}66-180 \mathrm{ft}(20-55 \\
\mathrm{m})\end{array}$ & $\begin{array}{l}98-164 \mathrm{ft}(30-50 \\
\mathrm{m})\end{array}$ & $\begin{array}{l}66-164 \mathrm{ft}(20-50 \\
\mathrm{m})\end{array}$ & $\begin{array}{l}164-230(50-70 \\
\mathrm{m})\end{array}$ & $\begin{array}{l}131-230 \mathrm{ft}(40- \\
70 \mathrm{~m})\end{array}$ \\
\hline Depth & $\begin{array}{l}2,300-5,740 \mathrm{ft} \\
(700-1,750 \mathrm{~m})\end{array}$ & $\begin{array}{l}2,300-4,921 \mathrm{ft} \\
(700-1,500 \mathrm{~m})\end{array}$ & $\begin{array}{l}4,265-16,404 \mathrm{ft} \\
(1,300-5,000 \mathrm{~m})\end{array}$ & $\begin{array}{l}2,300-8,858 \mathrm{ft} \\
(700-2,700 \mathrm{~m})\end{array}$ & $\begin{array}{l}2,300-11,482 \mathrm{ft} \\
(700-3,500 \mathrm{~m})\end{array}$ & $\begin{array}{l}2,300-6,562 \mathrm{ft} \\
(700-2,000 \mathrm{~m})\end{array}$ & $\begin{array}{l}2,300-6,562 \mathrm{ft} \\
(700-2,000 \mathrm{~m})\end{array}$ \\
\hline Structure & $\begin{array}{l}\text { Monocline in the } \\
\text { SE direction, } \\
\text { affected by some } \\
\text { normal faults } \\
\text { with slight } \\
\text { vertical offset }\end{array}$ & $\begin{array}{l}\text { Anticline, with } \\
\text { some high angle } \\
\text { inverse faults }\end{array}$ & $\begin{array}{l}\text { Continuation of } \\
\text { the monocline } \\
\text { from sector A } 1\end{array}$ & $\begin{array}{l}\text { Structural nose of } \\
\text { the Salado Arch }\end{array}$ & $\begin{array}{l}\text { Homoclinal tilted } \\
\text { on the E-NE } \\
\text { direction }\end{array}$ & $\begin{array}{l}\text { Narrow } \\
\text { anticlines } \\
\text { elongated in the } \\
\text { NW-SE } \\
\text { direction with } \\
\text { inverse faults }\end{array}$ & $\begin{array}{l}\text { Anticlines with } \\
\text { inverse faults }\end{array}$ \\
\hline $\begin{array}{l}\text { Expected } \\
\text { fluid }\end{array}$ & $\begin{array}{l}\text { Wet gas to Black } \\
\text { oil }\end{array}$ & $\begin{array}{l}\text { Dry gas (based } \\
\text { on observed } \\
\text { fluids in other } \\
\text { wells) }\end{array}$ & $\begin{array}{l}\text { Dry gas. The first } \\
\text { well drilled in the } \\
\text { MX-EFS is } \\
\text { located in this } \\
\text { sector }\end{array}$ & $\begin{array}{l}\text { Dry gas (based on } \\
\text { observed fluids in } \\
\text { other wells) }\end{array}$ & $\begin{array}{l}\text { Dry gas to Black } \\
\text { oil. Both gas and } \\
\text { liquids } \\
\text { production has } \\
\text { been observed }\end{array}$ & $\begin{array}{l}\text { Dry gas (based } \\
\text { on observed } \\
\text { fluids in other } \\
\text { wells) }\end{array}$ & $\begin{array}{l}\text { Dry gas (based } \\
\text { on observed } \\
\text { fluids in other } \\
\text { wells) }\end{array}$ \\
\hline
\end{tabular}




\section{PROBABILISTIC DECLINE-CURVE ANALYSIS REVIEW}

A probabilistic decline-curve analysis approach was chosen, given that it is relatively simple, it enables performing a play-wide assessment with available production data and more importantly quantifies the uncertainty on the resource size. The variable nature of the shale plays also supports the need of recognizing and quantifying this uncertainty. Capen (1976) points out that we (as industry and humans) are not very good at assessing the uncertainty, tending to understate it and overestimate the precision of our knowledge. As suggested by McVay and Dossary (2012), by reliably quantifying uncertainty we can minimize disappointments (both positive and negative), and make decisions with a clear view of the possible outcomes. This is particularly relevant for the Eagle Ford shale in Mexico given the early stage of the project.

\subsection{Probabilistic decline-curve analysis (PDCA) models}

\subsubsection{Decline-curve models for shales}

Decline-curve analysis has been widely used to estimate reserves both in conventional and unconventional fields. The Arps (1945) model was the preferred method before the massive development of shales in the last decade, and it continues to be used for shale wells. However, the industry realized that this may not be the most appropriate model since one of its underlying assumptions is that the subject well needs to be in boundary dominated flow (BDF) (Gong et al. 2011). The time that shale wells take to reach BDF varies significantly and tends to be long (months or years); if we try to forecast the 
production while they are in transient flow with the Arps model, we may overestimate reserves.

Several models have been published in recent years that try to improve production forecasts and reserves estimates reliability for shale wells (Clark et al. 2011; Duong 2010; Ilk et al. 2008; Valko and Lee 2010). These models have been subject of comparison and analysis by several studies trying to define the most appropriate and reliable model (Boulis et al. 2012; Gonzalez 2012; Joshi 2012; Kanfar and Wattenbarger 2012; Statton 2012). Results from these studies vary widely and there is no final word on which is the most reliable model; neither has been fully adopted by the industry.

\subsubsection{Probabilistic methodologies}

The high variability in shale's production makes a probabilistic methodology very suitable, as pointed out by Caldwell and Heather (1991). Since companies realized the advantages of a probabilistic approach (uncertainty quantification through a consistent and defendable methodology that also makes revision processes easier), they have increased their adoption. Benninger and Caldwell (1991) defined probabilistic reserve estimation as "simply a measure of confidence that can be applied to both production performance and volumetric estimation."

The simplest probabilistic method coupled with decline-curve analysis is Monte Carlo simulation of the Arps' model assuming probability distributions of the model 
parameters, as it was described by Benninger and Caldwell (1991) as well. However, knowledge of the parameters distribution is required, but rarely available, especially on the recent shale plays.

Jochen and Spivey (1996) proposed the bootstrap method which is a type of Monte Carlo simulation and does not require knowing the parameter distributions beforehand, and generated synthetic data sets from the original data set. The main assumption is that the data are independent and identically distributed, which would mean that the production is independent of time. However, this is not the most appropriate assumption, as pointed out by Cheng et al. (2005).

Cheng et al. (2005) showed that the bootstrap method reliability had significant room for improvement and developed a modified Bootstrap method (MBM). This improved method uses residuals of the fitted model and observed data at each time, groups them in blocks, and samples these blocks. This new approach does not require the observed data to be independent and identically distributed. As a result, it significantly improves the reliability of the forecasts reaching $68-83 \%$ realized coverage rates on expected $80 \%$ confidence intervals, compared to $22-44 \%$ accomplished by the bootstrap method (Cheng et al. 2005).

Gong et al. (2011) introduced a Bayesian approach for probabilistic decline-curve analysis, which does not modify historical production as the MBM does. The Bayes 
theorem estimates the probability of an event happening, given that another event already occurred. Applied to probabilistic decline-curve analysis, it estimates the probability function of decline-curve parameters, given the observed historical production. An analytical solution to estimate these probabilities is not always feasible and hence, Gong et al. (2011) proposed to use a MCMC simulation. This method is an algorithm to sample probability distributions based on Markov chains, which selects the sample on time $t$ based only on the sample drawn at time $t-1$ and not any sample drawn before that (Gong et al. 2011). This approach aligns theoretically with the nature of the production decline. After analyzing a set of horizontal fractured wells from the Barnett shale, the methodology reliably quantified the uncertainty, provided a narrower P90-P10 range and was faster than the MBM (Gong et al. 2011). This methodology was coupled with the Arps model only.

Gonzalez (2012) validated the reliability of the MBM and MCMC methods with a different data set achieving similar results. He also compared different combinations of the probabilistic methods and decline-curve models mentioned above, applied to horizontal, hydraulically fractured shale gas wells, and concluded that all decline-curve analysis (DCA) models were reasonably well calibrated when used with the MCMC method. Gonzalez (2012) also integrated volumetric data as prior information to enhance the reliability of the MCMC-Logistic growth model, especially at early times (6-12 months) of production history. 


\subsection{Description of selected PDCA methodology}

As described by Cheng et al. (2005), the ideal probabilistic method should be consistently reliable (e.g. it obtains a realized confidence range of $80 \%$, for $80 \%$ estimated confidence intervals). In this thesis, a model/methodology that is reliable for both shale oil and gas wells is required, given that these are the observed fluids in the US-EFS and the expected ones in the MX-EFS. Gonzalez (2012) showed that several decline-curve models were all reasonably reliable for shale gas, and Gong (2013) showed that the Duong model achieved reasonable reliability for oil wells in the USEFS.

Based on the above, the Duong model coupled with the MCMC methodology was chosen as the primary methodology to analyze and forecast production. As mentioned before, Gonzalez (2012) showed that prior knowledge of the in-place or recoverable volumes can enhance the reliability of the results, and hence prior information was incorporated as part of the methodology. The output of this part of the analysis was a distribution of EUR at 20 years for each individual well, and the corresponding model parameters distributions.

The Duong model assumes long-term linear flow and that no boundary is observed during the well life (Duong 2010); because of this assumption it may overestimate future production and hence reserves, as pointed out by Gonzalez (2012) . Additionally, boundary dominated flow has been observed in some wells both in the US-EFS and MX- 
EFS, which supports the need to adjust the model. To correct this effect, Gong (2013) proposed shifting to the Arps model at a minimum decline rate. This minimum decline rate varies throughout the wells, and it is more appropriate to model it as a random variable, rather than a single value. After imposing this correction, a modified EUR distribution at 20 years and model parameters for each individual well were calculated.

Up to this point, the methodology was applied to estimate the reserves of existing individual wells; however, to estimate the total prospective resources of each sector a type curve applicable to each of them was required. To achieve this, Gong (2013) combined the individual-well results into a single dataset, from which values for the decline-curve parameters and resulting EUR were sampled with Monte Carlo simulation to estimate sector type curves and EUR distributions. These distributions, together with well-spacing assumptions and sector areas were combined to generate the prospective resources estimates. Fig. 2 summarizes the methodology described in this section and was applied in the following sections. 


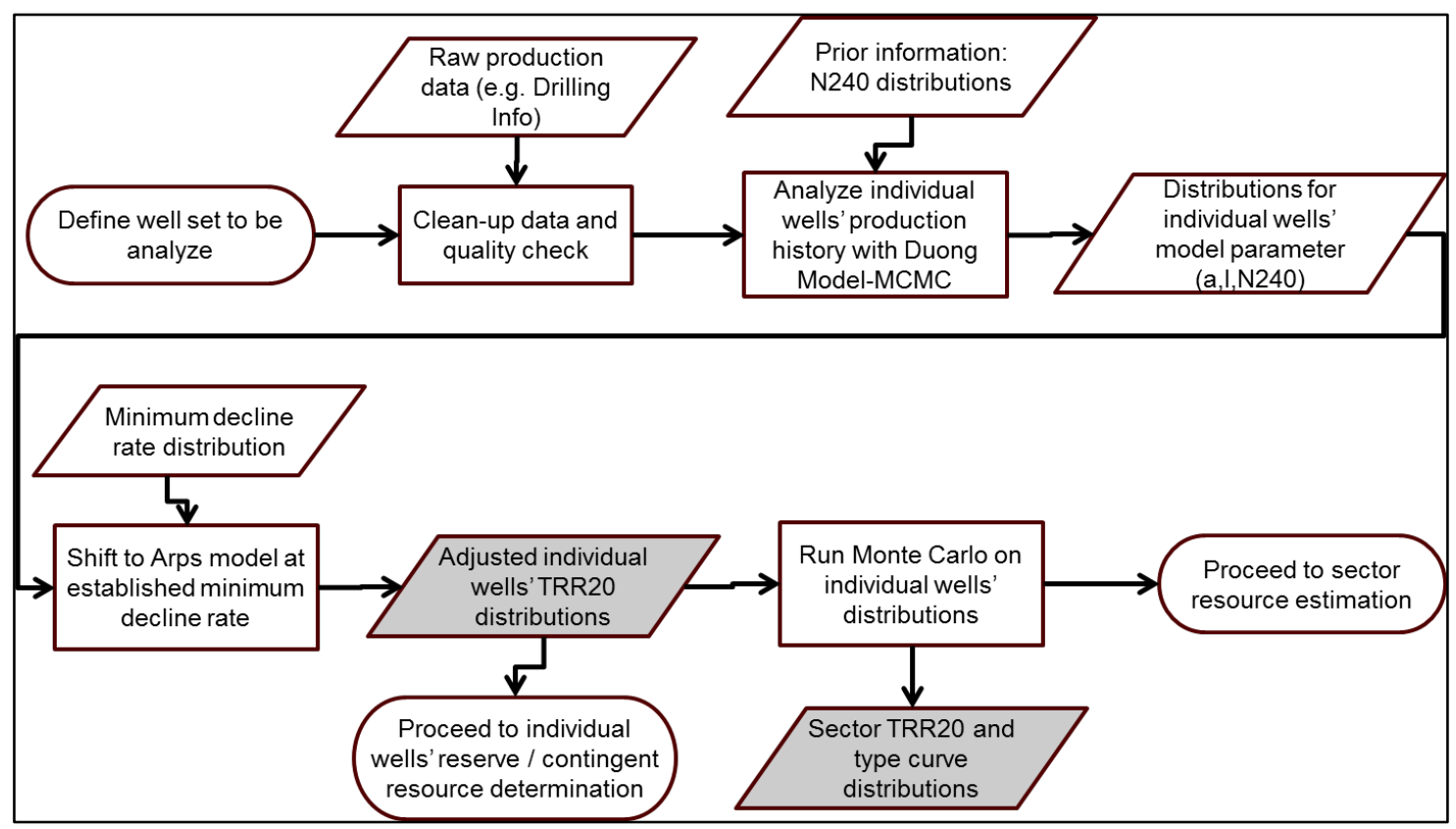

Fig. 2- Production data analysis and forecast methodology for individual wells and sector type curves 


\section{PROSPECTIVE RESOURCES}

As per the PRMS, prospective resources are defined as: "those quantities of petroleum estimated, as of a given date, to be potentially recoverable from undiscovered accumulations by application of future development projects." It is important to highlight that these are undiscovered resources and hence large uncertainty can be expected.

\subsection{Identification of analog sub-areas in the US-EFS}

The first step of the approach was to define suitable and appropriate analogs in the USEFS. Analogs are widely used specially at early stages of a project, and the validity of these analogs areas is supported by the proximity of the area, the common depositional environments and geologic history.

Analogs for each of the MX-EFS sectors were defined based on the available geologic information both in the US-EFS and MX-EFS (TOC, thermal maturity, depth, thickness, and facies). To decide which of these variables is more appropriate to define the analog areas, the relation of each of them with the production history was studied and the findings are explained below.

The characteristics mentioned above and the cumulative production of oil and gas of individual wells at 6 and 12 months were analyzed. Wells in the southern part of the US- 
EFS (Maverick, Zavala, Frio, Kinney, Uvalde, Medina, Dimmit, Webb, La Salle, McMullen and part of the Atascosa counties) were considered, given the proximity to the MX-EFS and greater similarities on the characteristics of interest.

I first looked at the influence of TOC and divided the area described above into 4 sectors: less than $2 \%, 2$ to $4 \%, 4$ to $6 \%$ and more than $6 \%$ TOC, based on the lower USEFS TOC maps done by Tian et al. (2013). TOC tend to increase on the northwest direction of this area. In theory, the higher TOC, the greater hydrocarbon source potential (all other factors being equal), hence impacting the amount of oil and gas in place. However, when looking at the data (Fig. 3) there is no correlation between historic production and TOC; in fact the sector with more than 6\% TOC show lower cumulative production for both oil and gas. Even though the resource in place may be greater in higher TOC sectors, other factors have a stronger influence on the reservoir performance and hence TOC by itself should not be a primary factor to define the analog areas. 


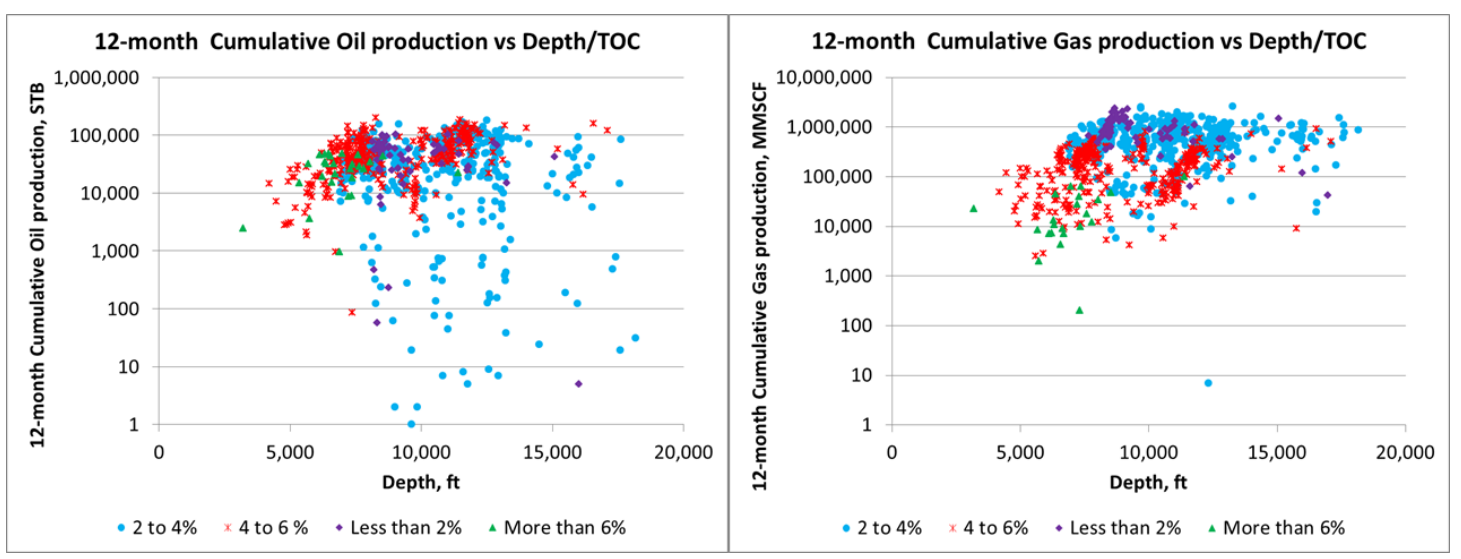

Fig. 3- Effects of depth and TOC on cumulative oil and gas production

I then looked at the lower US-EFS thickness and maturity together, dividing the same southern part of the US-EFS into 5 sectors: overmature/100-150 ft thick, overmature/150-200 ft thick, mature/50-100 ft thick, mature/100-150 ft thick, mature/150-200 ft thick, based on thickness maps of the lower US-EFS done by Tian et al. (2012) and the maturity developed by Cardneaux (2012). Despite the lack of any theoretical relation between thickness and maturity, it was decided to analyze them together because of their corresponding geographic distribution (i.e. the single overmature area can be divided into thick and thin sectors, and the single mature area can be divided in 3 sectors based on thickness). In theory, the thicker the shale the greater hydrocarbon source potentially in place (all other factors being equal). As described by Boyer et al. (2006), maturity in conjunction with the kerogen type determines the fluid present in the reservoir: oil, gas or both.

When looking at cumulative oil production, there is no evidence of better performance of thicker sectors regardless of the maturity (Fig. 4). Wells with very low oil production 
are found in the overmature area (as expected), but many wells closer to the mature sectors have produced as much oil as those in the mature sectors. Overmature sectors have greater gas production than mature areas (as expected), but thickness doesn't seem to have any effect. In mature areas, slightly better performance is observed in the thickest sector. Based on this, thickness has a slight impact on gas production only in mature sectors and was considered to define the analog sectors.

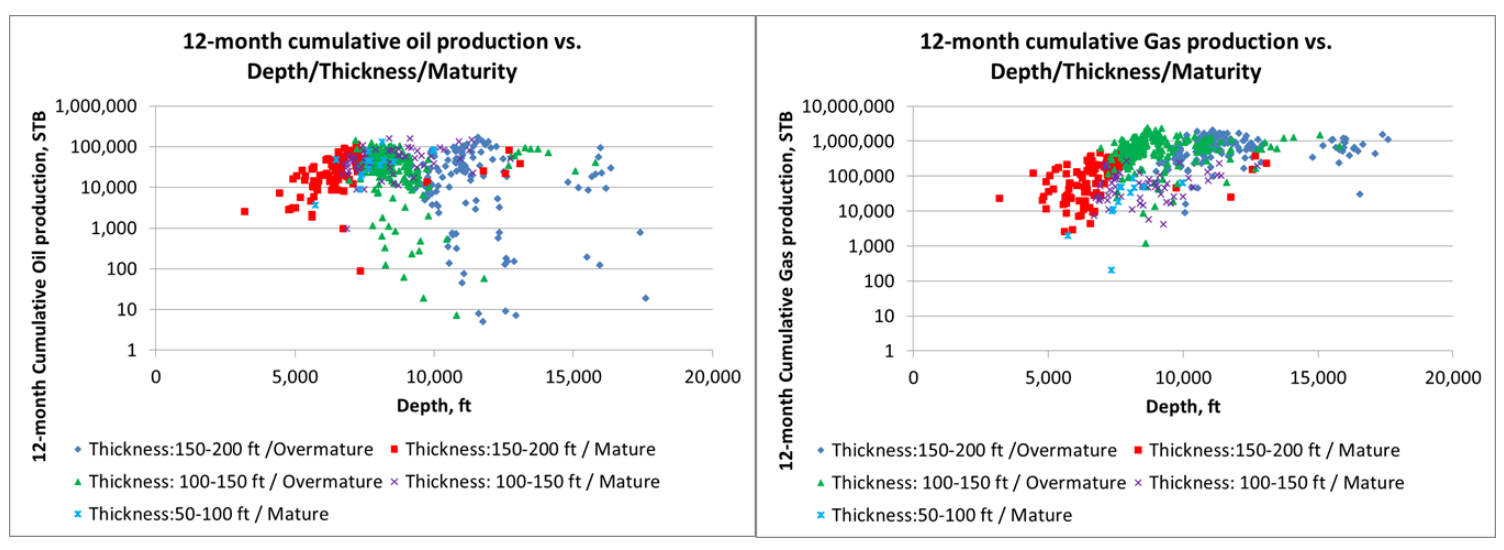

Fig. 4- Effects of thickness and thermal maturity on cumulative oil and gas production

Another observation that was derived from this analysis is that depth affects both oil and gas cumulative production. A positive correlation is observed up to a certain depth range $(6,000-8,000 \mathrm{ft})$ and after that no effect is observed with increasing depth. Based on the described observations, depth was selected as a criterion to define the analog sectors. Any area with a greater depth than the depths of the MX-EFS sectors was excluded. The defined analog sectors in the US-EFS based on the analysis described in this section are described in Table 4 and their location can be observed in Fig. 5. 
The North Mature, and South Overmature sectors contain mostly one fluid type (black oil and dry gas respectively); and only gas production in the South Thick-Mature sector was analyzed. The South Mature sector is the only analog sector with a mix of black oil, volatile oil and condensate wells, and needs a special treatment when selecting the appropriate GOR.

It is relevant to highlight that this sector definition can be refined with additional information/maps (e.g. permeability, pressure gradient, fluid types, natural fractures or mineral composition, completion techniques) that may have stronger influence on the reservoir performance. 
Table 4-Defined US-EFS analog sectors

\section{US-EFS Analog sector}

MX-EFS Sector

South Mature

Reference counties: Maverick, Zavala, Uvalde, Medina, Frio, Dimmit

TOC: $5-12 \%$

Depth: 0 to $5,750 \mathrm{ft}$

A1

Thickness: 50 to $200 \mathrm{ft}$

Shale Volume: $0.4-1$

Well type to be considered: Oil and gas wells

North Mature

Reference counties: Atascosa, Karnes, DeWitt, Gonzalez

TOC: $5-8 \%$

Depth: 0 to $11,500 \mathrm{ft}$

Thickness: 25 to $200 \mathrm{ft}$

Shale Volume: $0.4-1$

Well type to be considered: Oil and gas wells

South Thick Mature

Reference counties: Maverick, Zavala, Dimmit

TOC: $5-10 \%$

Depth: 0 to $8,900 \mathrm{ft}$

Thickness: 150 to $200 \mathrm{ft}$

Shale Volume: $0.5-1$

Well type to be considered: Only gas wells

South Overmature

Reference counties: Webb, La Salle, McMullen, Dimmit counties

TOC: $2-4 \%$

Depth: 8,000 to $14,000 \mathrm{ft}$

Thickness: 100 to $200 \mathrm{ft}$

Shale Volume: $0.5-1$

Well type to be considered: Only gas wells

A2, C, E

B1/B2/B3, F1/F2 


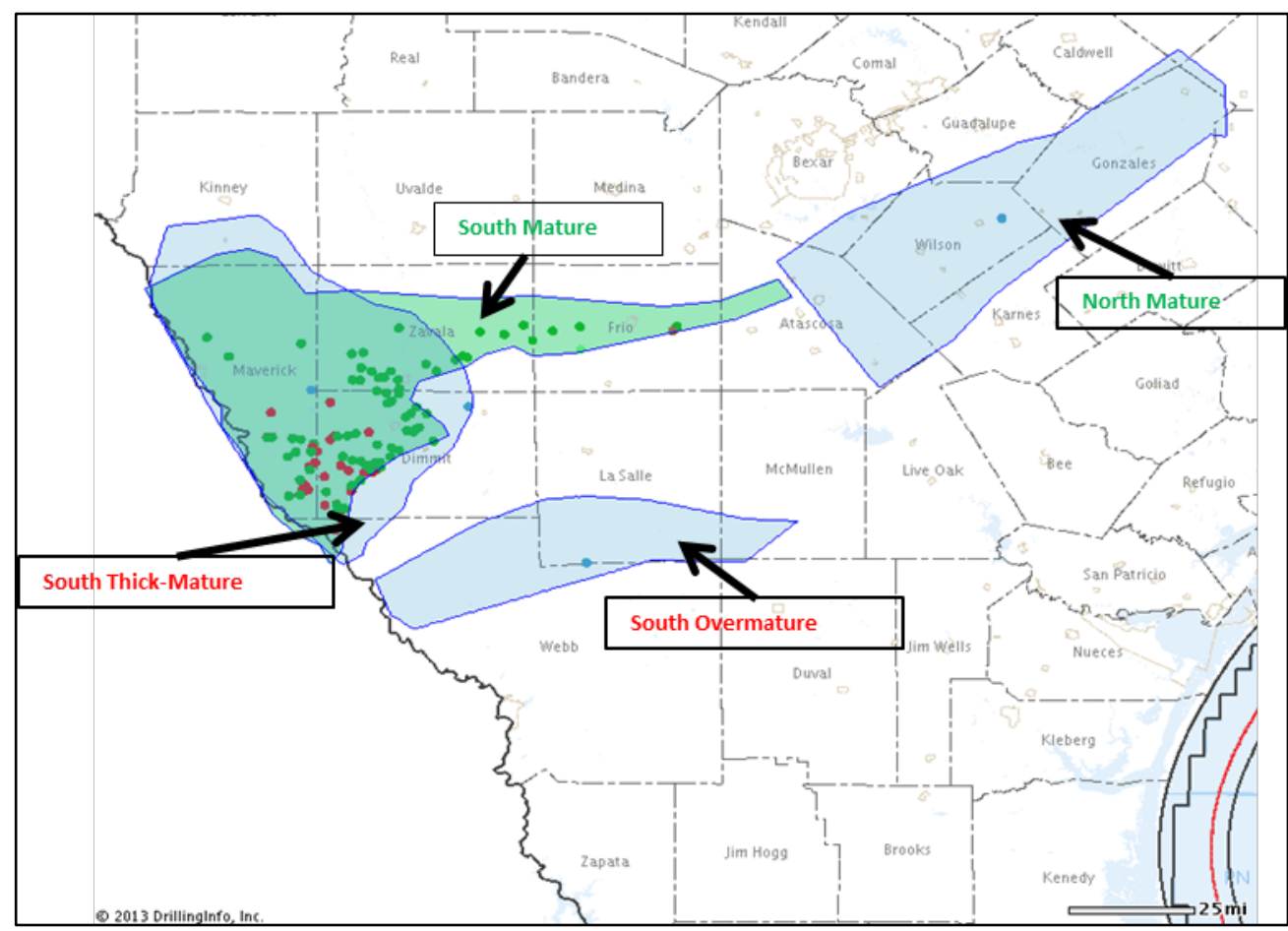

Fig. 5- Defined US-EFS analog sectors

\subsection{Generate probabilistic type curves for each analog sector}

The general approach and methodology to estimate the prospective resources was described in Sections 3.2. A key component of the approach is the generation of probabilistic type curve or EUR distributions for each MX-EFS sector. The production of existing wells in each of the US-EFS analog sectors was analyzed with the methodology described in Section 3.2. The key assumptions and inputs are described below. 


\subsubsection{Prior distribution of cumulative production after 20 years (N240)}

As described in Section 3.1.2, prior information can enhanced the results in a Bayesian probabilistic assessment. For this study, the results from a probabilistic reservoir simulation study performed by Gong (2013) on the US-EFS were chosen as prior distributions for the type curve generation.

Gong (2013) divided the US-EFS into 8 regions and developed a reservoir simulation model for each of them based on available information. In all models 12 fracture stages and 2 fractures per stage were chosen as completion design. Monte Carlo simulation was coupled with the reservoir simulation model of each region, to account for the variability of the different reservoir characteristics. Distributions for fracture and matrix permeability, thickness, initial pressure and bubble point pressure were introduced to the model. A distribution for N240 was estimated for each of the regions defined by Gong (2013).

The regions defined by Gong (2013) are similar to the US-EFS analog sectors defined in Section 4.1, and although not exactly the same, N240 prior distributions from Gong (2013) can be reasonably applied.

Table 5 shows the US-EFS analog sectors and selected equivalent regions and N240 distributions. 
Table 5- Equivalent regions from Gong (2013) and prior N240 distributions

\begin{tabular}{|c|c|c|c|}
\hline $\begin{array}{c}\text { US-EFS analog } \\
\text { sector }\end{array}$ & $\begin{array}{c}\text { Gong (2013a)- } \\
\text { Region }\end{array}$ & Average N240 & $\begin{array}{c}\text { Standard Deviation } \\
\text { of In(N240) }\end{array}$ \\
\hline South Mature & PR-1 & 123,733 STB & 1.08 \\
\hline North Mature & PR-6 & 458,351 STB & 0.88 \\
\hline $\begin{array}{c}\text { South Overmature/ } \\
\text { South Thick Mature }\end{array}$ & PR-8 & 2.195 BSCF & 1.15 \\
\hline
\end{tabular}

\subsubsection{Minimum decline assumptions}

The need to shift to the Arps model to better model the actual flow behavior once it reaches BDF was explained in Section 3.2. It was also mentioned that the transition to BDF does not occur at the same time in all wells, as it depends (directly or indirectly) of several variables (e.g. fluid properties, pressure, fracture length and width, permeability) and that it is more appropriate to model it as a random variable.

The distribution of the minimum decline at which the model should shift to the Arps model was obtained by analyzing existing wells in the US-EFS. Only wells with a long and smooth production history were considered for this analysis. First, a subset of wells that have reached BDF was identified and the distribution of the decline rate at which they transitioned to BDF was estimated. This distribution was missing the wells still in transient flow, and hence, the complete distribution was approximated by looking at the current decline rates of these wells and assuming they would follow a similar distribution of decline rates to shift to BDF than the one observed for wells already in BDF. 
In addition to the analysis described above, Gong (2013) observed that the minimum decline and the Duong model parameter $l$ are strongly correlated. This simplifies the modeling of the minimum decline rate distribution because it can be directly derived from the distribution generated for $l$. Gong (2013) also observed a weak correlation of the minimum decline rate with well spacing and introduced this correlation into the model.

\subsubsection{Gas/oil ratio (GOR) assumptions}

Production forecast in horizontally fractured shale wells with two-phase flow is more challenging because of the additional complexities caused by changes of phases and relative permeability. In this study, two-phase flow is observed in wells in the North Mature and South Mature US-EFS analog sectors. To estimate the flow of oil and gas, the historic oil production was first analyzed with the methodology described in Section 3.2 and the N240 assumptions described above. For the gas volumes estimation a GOR distribution /model was applied to the oil production. The GOR distributions/model used for the two mentioned sectors were developed by Gong (2013).

Gong (2013) analyzed the historic GOR on existing US-EFS wells, by grouping the wells according to their fluid type: black oil, volatile oil or condensate. In all of them the GOR tends to increase over time with a varying slope. Based on this analysis, Gong (2013) generated a distribution of linear slopes of GOR versus time and a distribution of 
initial GOR for each type of fluid. The combination of these two distributions enabled the estimation of a distribution of potential GOR over time.

The North Mature sector in the US-EFS has primarily black oil wells as can be observed on the fluid type map done by Tian et al. (2012), hence the Black Oil GOR model/distribution was used for it. The South Mature sector has wells with various fluid types and the three corresponding GOR distributions/models were used to analyze this region. The results of each of them were combined into a single EUR distribution. In this way, the uncertainty of the types of fluid that could be found in the MX-EFS is accounted for and quantified. The South Overmature and South Thick Mature sectors are considered to have dry gas fluid and hence no GOR model is required for these sectors.

\subsection{Well-spacing assumptions}

The well-spacing assumptions applied to the MX-EFS sectors were based primarily on the equivalente regions defined by Gong (2013) and the US-EFS analog sectors defined in this thesis. Gong (2013) looked at current well spacing used in each of the regions he defined in the US-EFS, and identified the highest well densities in each of them to estimate a representative well spacing of each region. Gong (2013) recognized that there is uncertainty in future well spacing caused by different well designs and completion practices, and defined the well spacing as a random variable with a unifrom distribution, in which the P50 is the current highest well density. The lower limit of the distribution is $30 \mathrm{acre} / \mathrm{well}$ and the upper limit is two times the well spacing derived from the current 
highest well density in each region. The P50 values from Gong (2013) region 8 were assumed for the South Overmature and South Thick Mature sectors. The North Mature and South Mature area have already a high well density ( $\sim 11$ wells per section) which would be too optimistic to assumed for MX-EFS, given it is structurally more complex and at a very early stage of development. For these reasons, a higher well spacing P50 value sof 320 acres/well was assumed. Table 6 shows the selected Gong (2013) regions and P50 well spacing and corresponding Gong (2013) region when applicable.

Table 6- Selected well spacing for each MX-EFS sector

\begin{tabular}{|c|c|c|c|}
\hline MX-EFS Sectors & $\begin{array}{c}\text { US-EFS analog } \\
\text { sector }\end{array}$ & $\begin{array}{c}\text { Gong (2013a)- } \\
\text { Region }\end{array}$ & $\begin{array}{c}\text { P50 well spacing } \\
\text { (acre/well) }\end{array}$ \\
\hline A1 & South Mature & NA & 320 \\
\hline D1/D2 & North Mature & NA & 320 \\
\hline B1/B2/B3, F1/F2 & South Overmature & PR-8 & 320 \\
\hline A2, C, E & South Thick Mature & PR-8 & 320 \\
\hline
\end{tabular}

The total areas of each sector were also adjusted by an effective drillable area factor distribution to account for urban buildings, faults or remote areas that cannot be drilled. This factor varies from 0.75 to 1 .

\subsection{Aggregation methodology}

Under the PRMS Guidelines it is recommended to use arithmetic aggregation for reporting purposes, and statistical aggregation for business units or corporate portfolio analyses. The latter is a more appropriate approach given the purpose of this thesis. The PRMS also points out that "in practice, there is likely to be a large degree of dependence 
between reservoirs in the same field." The aggregation methodology should account for this dependence. The statistical aggregation methodology selected was the one proposed by Gong (2013), in which the level of dependency within each region is represented by a triangular distribution between 0 (independent) and 1 (fully dependent or arithmetic).

\subsection{Results and discussion}

EUR at 240 months distributions and corresponding oil and gas production type curves were estimated through the methodology and assumptions described above for each analog sector in the US-EFS. The North Mature and South Overmature areas resulted with the best performing type curves for oil and gas respectively, while the South Mature and South Thick-Mature sectors resulted in lower production type curves. The summary of these results is shown in Table 7.

Table 7-EUR at 240 months distributions for each US-EFS analog sector

\begin{tabular}{|c|c|c|c|c|c|c|c|c|c|c|c|}
\hline & & \multicolumn{5}{|c|}{ Oil, MSTB } & \multicolumn{5}{|c|}{ Gas, BSCF } \\
\hline $\begin{array}{c}\text { MX- } \\
\text { EFS } \\
\text { sector }\end{array}$ & $\begin{array}{l}\text { US-EFS } \\
\text { Analog } \\
\text { Sector }\end{array}$ & Avg & STD & P90 & P50 & P10 & Avg & STD & P90 & P50 & P10 \\
\hline $\mathrm{A} 1$ & $\begin{array}{l}\text { South } \\
\text { Mature }\end{array}$ & 100 & 109 & 14 & 64 & 228 & 1.13 & 2.03 & 0.06 & 0.42 & 2.90 \\
\hline D1/D2 & $\begin{array}{l}\text { North } \\
\text { Mature }\end{array}$ & 235 & 163 & 82 & 192 & 437 & 0.74 & 0.70 & 0.16 & 0.54 & 1.56 \\
\hline $\begin{array}{l}\mathrm{B} 1 / \mathrm{B} 2 / \mathrm{B} \\
3, \mathrm{~F} 1 / \mathrm{F} 2 \\
\end{array}$ & $\begin{array}{c}\text { South } \\
\text { Overmature }\end{array}$ & & & & & & 3.41 & 2.76 & 0.79 & 2.72 & 7.17 \\
\hline $\mathrm{A} 2, \mathrm{C}, \mathrm{E}$ & $\begin{array}{l}\text { South Thick } \\
\text { Mature }\end{array}$ & & & & & & 0.90 & 0.79 & 0.12 & 0.70 & 1.95 \\
\hline
\end{tabular}


The relatively narrow P90-P10 range observed in the oil volumes for North Mature region results indicates the low variability on the performance of the wells in this sector. The low gas volumes estimated are the result of using the Black Oil GOR model/distribution. The production type curves for this sector are shown in Fig. 6.

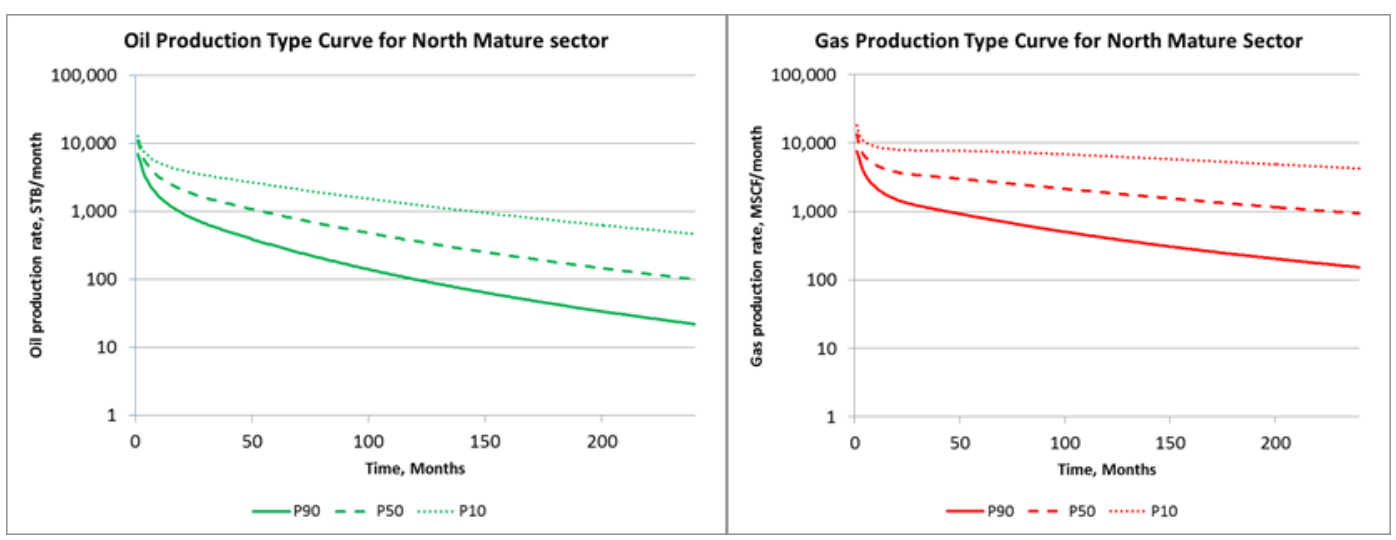

Fig. 6- Oil and gas production type curves for the North Mature US-EFS sector

The South Mature sector presents lower oil production and greater variability on it compared to the North Mature sector. The estimated gas volumes have a fairly large P90-P10 range as a result of the uncertainty on the type of fluid that can be found and the corresponding GOR model/distribution. The P90-P10 ranges obtained when using only one of the GOR models are smaller, and the resulting type curves for each case is shown in Fig. 7. 


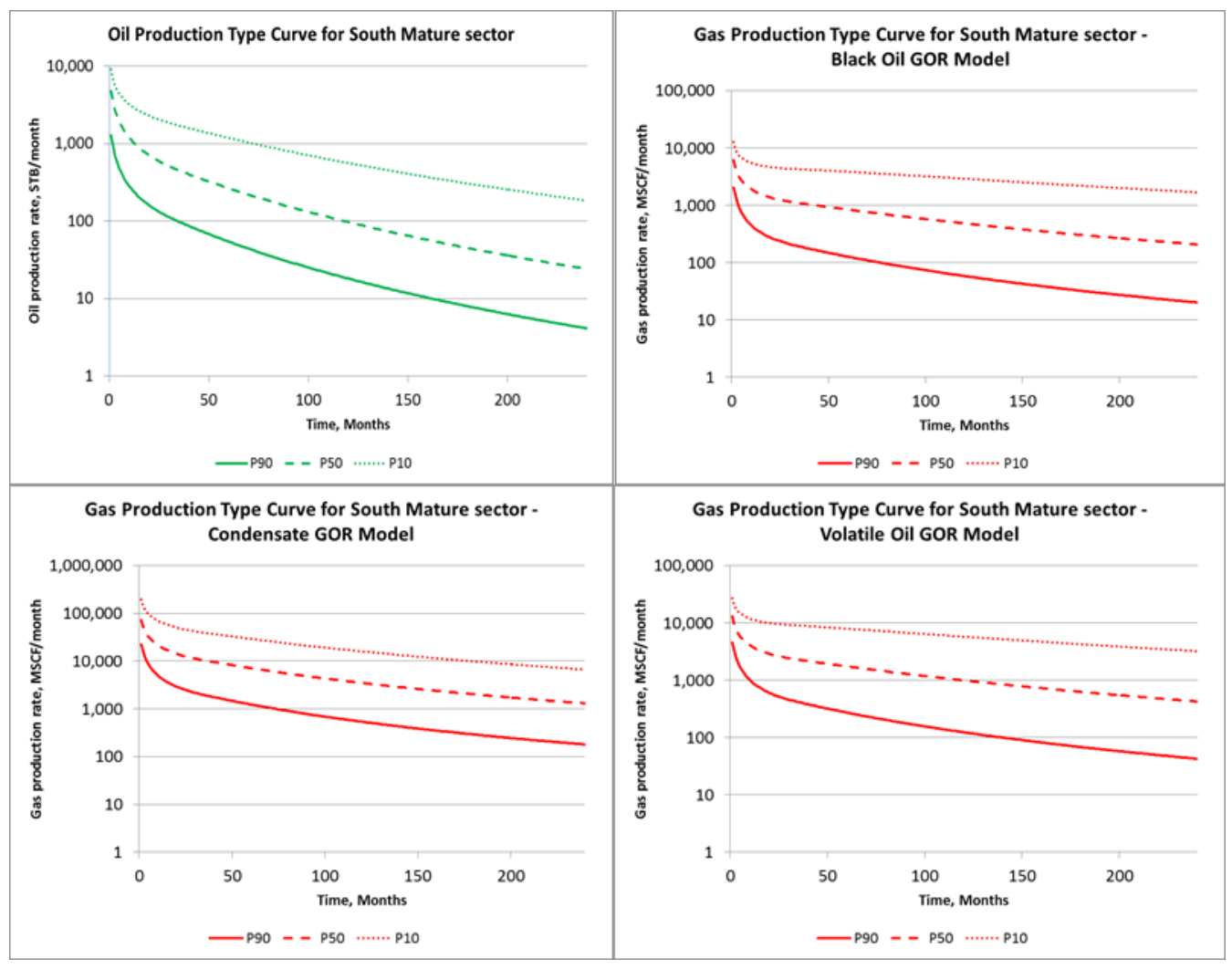

Fig. 7- Oil and gas production type curves for the South Mature US-EFS sector with different fluid type assumptions

The wide P90-P10 range in the South Overmature sector indicates the relatively large variability of the well performance within that sector. Meanwhile, the South ThickMature sector obtained lower volumes and wider variability in its gas production. The production type curves for these two sectors are shown in Fig. 8. 


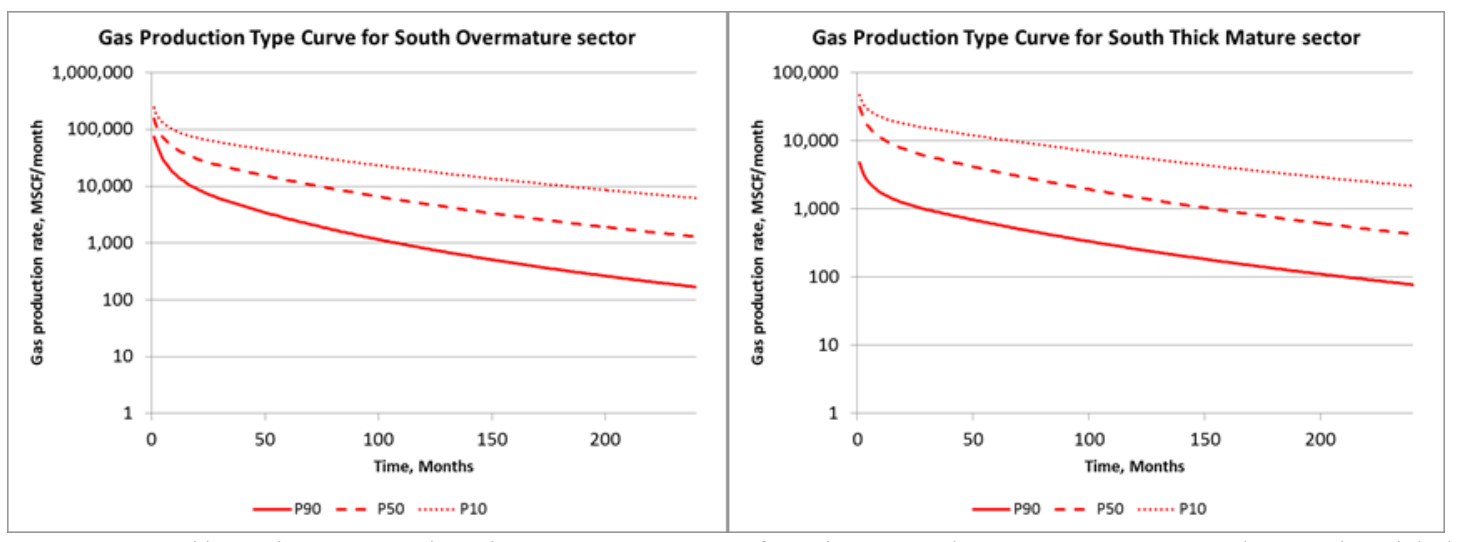

Fig. 8- Oil and gas production type curves for the South Overmature and South ThickMature US-EFS Sectors

To estimate the total prospective resources for the MX-EFS, the EUR distributions discussed above were combined with the well-spacing assumptions described in Section 4.3, the area for each defined sector in the MX-EFS and the aggregation methodology described in Section 4.4. The uncertainty of all three factors contributes to the resulting range of prospective resources, which has a P90-P10 range of 527-7,268 MMSTB and 17-217 TSCF. These wide ranges reflect the very early stage of the play, and hence, high uncertainty is expected on several factors. The estimates for each sector and the entire area are shown in Table 8.

Based on the results by sector, D1/D2 appears as the most attractive sector for oil production, whereas sectors $\mathrm{F} 1 / \mathrm{F} 2$ and $\mathrm{B} 1 / \mathrm{B} 2 / \mathrm{B} 3$ have the greatest gas potential. When looking at the total resources, the P50 estimate for gas (37 TSCF) is slightly greater than the current gas reserves for Mexico (34.8 TSCF), which highlights the magnitude and 
relevance of the MX-EFS. For oil, the P50 estimate (1,139 MM STB) represents 10\% of the current 1P reserves (10 billion STB), which is a significant number as well.

Table 8 - Prospective resources for the MX-EFS by sector

\begin{tabular}{|c|c|c|c|c|c|c|c|}
\hline & \multirow{2}{*}{\multicolumn{3}{|c|}{ Oil, Million STB }} & \multirow{2}{*}{\multicolumn{3}{|c|}{ Gas, TSCF }} \\
\hline & & & & & & & \\
\hline $\begin{array}{l}\text { MX-EFS } \\
\text { sector }\end{array}$ & $\begin{array}{l}\text { US-EFS } \\
\text { Analog } \\
\text { Sector }\end{array}$ & P90 & P50 & P10 & P90 & P50 & P10 \\
\hline $\mathrm{A} 1$ & $\begin{array}{c}\text { South } \\
\text { Mature }\end{array}$ & 203 & 453 & 2,868 & 2 & 5 & 30 \\
\hline $\mathrm{D} 1 / \mathrm{D} 2$ & $\begin{array}{c}\text { North } \\
\text { Mature }\end{array}$ & 324 & 686 & 4,400 & 1 & 2 & 13 \\
\hline $\mathrm{B} 1 / \mathrm{B} 2 / \mathrm{B} 3$ & $\begin{array}{c}\text { South } \\
\text { Overmature }\end{array}$ & & & & 3 & 6 & 34 \\
\hline $\mathrm{F} 1 / \mathrm{F} 2$ & $\begin{array}{c}\text { South } \\
\text { Overmature }\end{array}$ & & & & 8 & 17 & 100 \\
\hline $\mathrm{A} 2$ & $\begin{array}{l}\text { South Thick } \\
\text { Mature }\end{array}$ & & & & 1 & 2 & 14 \\
\hline $\mathrm{C}$ & $\begin{array}{l}\text { South Thick } \\
\text { Mature }\end{array}$ & & & & 1 & 3 & 18 \\
\hline E & $\begin{array}{l}\text { South Thick } \\
\text { Mature }\end{array}$ & & & & 1 & 2 & 9 \\
\hline & $\begin{array}{l}\text { Total MX- } \\
\text { EFS } \\
\end{array}$ & 527 & 1,139 & 7,268 & 17 & 37 & 217 \\
\hline
\end{tabular}

The results of this work should provide a more reliable estimate of the size and uncertainties of the resources in the Mexican Eagle Ford shale than previous estimates obtained with less objective methodologies. The gas estimates capture the range estimated by PEMEX of 27-87 TSCF (P90-P10) (PEMEX 2011) and suggest a greater upside potential. The EIA deterministic estimate of 498 TSCF (EIA 2011b) is far above of the range and seems unlikely based on this thesis. This significant difference can be 
partly explained by the fact that the EIA estimate is based on a prospective area of $30,000 \mathrm{mi}^{2}$, more than twice the prioritized area considered in this thesis. Also, their methodology assumes a higher concentration of resources than those that the estimates from this thesis suggest. It is worth highlighting that no previous estimates for oil have been done for the MX-EFS. 


\section{RESERVES AND CONTINGENT RESOURCES}

\subsection{Applicable wells}

As of March 2013, five wells had been drilled in the MX-EFS with various results, shown in Table 9. The methodology used to estimate the prospective resources can only be used when enough production data is available. Only two wells have been producing and hence are the only ones to which the methodology of this study was applied. They are also the only ones whose volumes could be classified as reserves. Volumes associated with wells $\mathrm{C}$ and $\mathrm{D}$ would be classified as contingent resources, given that well C is waiting for infrastructure and Well D was sanctioned as non-commercial under the economic conditions at that time. The corresponding sector type curves shown in Section 4.5 were used for these wells. Volumes associated with well E would be classified as non-recoverable resources.

Table 9- Wells drilled and completed in the MX-EFS as of March 2013

\begin{tabular}{|c|c|c|c|}
\hline Well & $\begin{array}{c}\text { Completion } \\
\text { date }\end{array}$ & $\begin{array}{l}\text { MX-EFS } \\
\text { Sector }\end{array}$ & Result \\
\hline A & $03-2010$ & $\mathrm{~B} 1 / \mathrm{B} 2 / \mathrm{B} 3$ & Commercial-Producing \\
\hline B & 01-2012 & $\mathrm{F} 1 / \mathrm{F} 2$ & Commercial-Producing \\
\hline $\mathrm{C}$ & 03-2012 & $\mathrm{B} 1 / \mathrm{B} 2 / \mathrm{B} 3$ & $\begin{array}{l}\text { Commercial-Waiting for } \\
\text { infrastructure }\end{array}$ \\
\hline $\mathrm{D}$ & 04-2012 & A1 & Non-commercial \\
\hline $\mathrm{E}$ & 06-2012 & A1 & Non-productive \\
\hline
\end{tabular}




\subsection{Economic evaluation}

To estimate the reserves volumes of existing producing wells (A and B), an economic limit (under current operating costs and gas prices) needs to be estimated for them. Economic evaluation becomes more relevant for classifying the volumes associated with offset wells, because they need to offer an attractive return to provide certainty that they will be drilled in the near future.

The main assumptions for the economic evaluation are shown in Table 10. Working interest in the evaluation is $100 \%$, since PEMEX is the only operator in Mexico. The basis differential is relative to the Henry-Hub gas price and the gas price taken was as of May 23, 2013. The costs estimates were provided by PEMEX. A gas shrinkage factor of $5 \%$ was assumed to account for gas consumed at the well site. It is important to highlight that the economic evaluation did not consider probabilistic economic variables given the lack of relevant data available. The results from the economic evaluation are only used to determine whether the volumes should be classified as reserves or as contingent resources. 
Table 10 - Economic assumptions to determine offset wells resource classification

\begin{tabular}{|c|c|c|}
\hline Assumptions & Well A & Well B \\
\hline Drilling and Completion costs, \$MM & 5.8 & 7.0 \\
\hline Tie-in costs, \$MM & 0.6 & 0.6 \\
\hline Variable operating cost, \$/MSCF & 0.01 & 0.01 \\
\hline Gas price, \$/MSCF & 4.22 & 4.22 \\
\hline Gas basis differential, \$/MSCF & 1.00 & 1.00 \\
\hline
\end{tabular}

\subsection{Results and discussion}

To estimate the EUR for each of the applicable existing wells, the production history was analyzed with the same methodology described in Section 3.2 (MCMC-Duong model followed by Arps model at minimum decline). Table 11 shows the resulting EUR distributions and the corresponding type curves are shown in Fig. 9 and Fig. 10. The EUR distribution for Well A is captured by the type curve estimated for the South Overmature region; whereas for Well B only the P10 lies beyond the range of the type curve. This observation is an indication of the type curves estimated for these sectors are reasonable. After doing an economic evaluation considering only the operating costs, the economic life of the well can be extended until the end of the 360 months forecast.

Table 11- Forecasted EUR distribution for each existing producing well in MMSCF

\begin{tabular}{|c|c|c|c|c|c|}
\hline Well & $\begin{array}{c}\text { Cumulative } \\
\text { Production }\end{array}$ & Mean & P90 & P50 & P10 \\
\hline A & 694 & 1,863 & 1,280 & 1,701 & 2,681 \\
\hline B & 477 & 5,263 & 2,622 & 4,926 & 8,556 \\
\hline
\end{tabular}




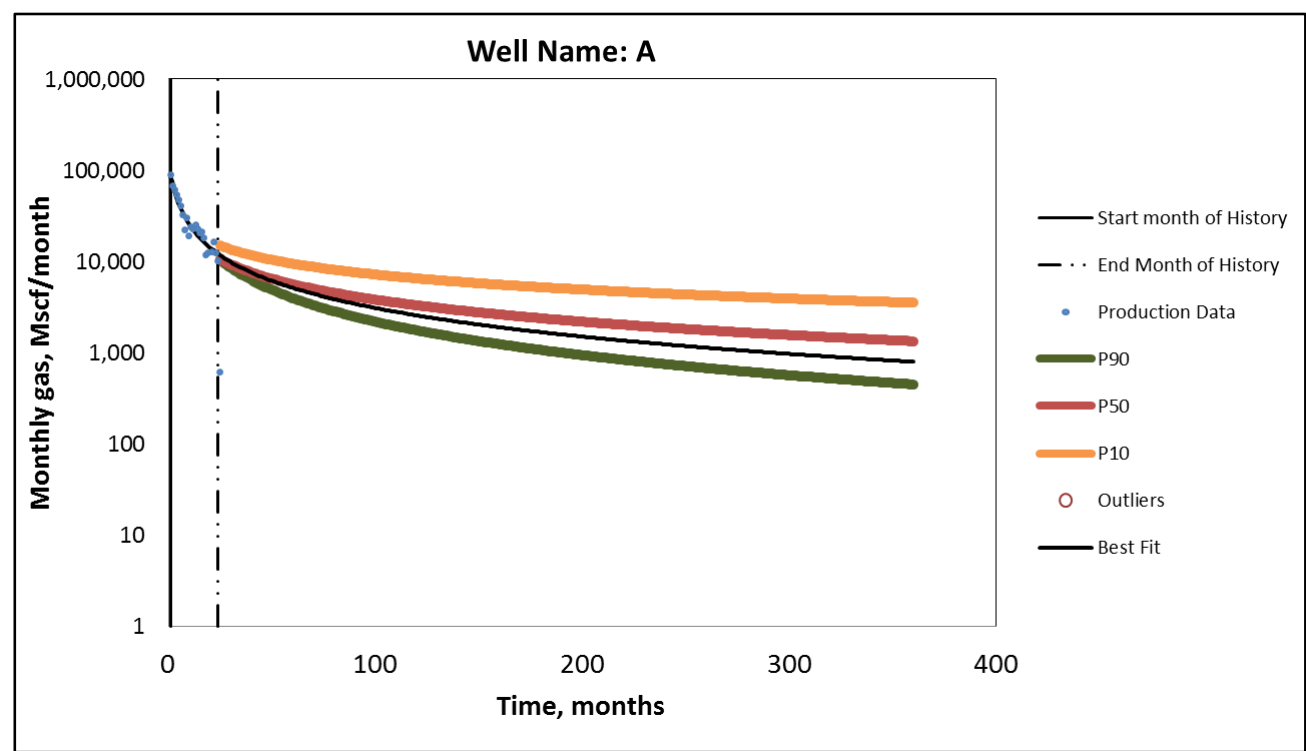

Fig. 9- Production forecast for well A

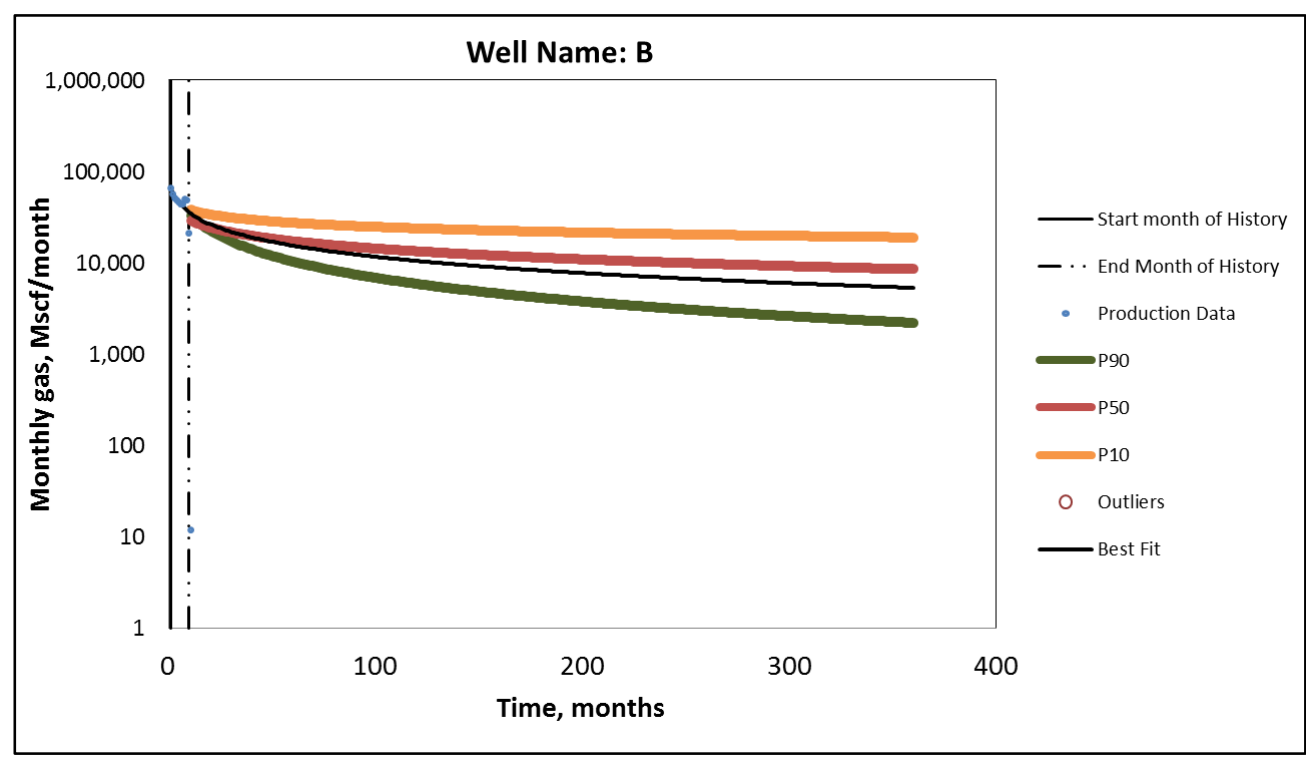

Fig. 10- Production forecast for well B 
Volumes expected to be extracted from offset locations of existing wells can be classified as reserves if they have certainty to be technical and commercially feasible. For each of the existing producing wells, 6 offset well locations were assumed to have certainty of the resource being there. The EUR distribution consider for each of the wells was based on the forecast obtained for Well A and B respectively, and a Monte Carlo simulation was run to add the 6 wells volumes. The resulting total distributions are shown in Fig. 11 and Fig. 12.

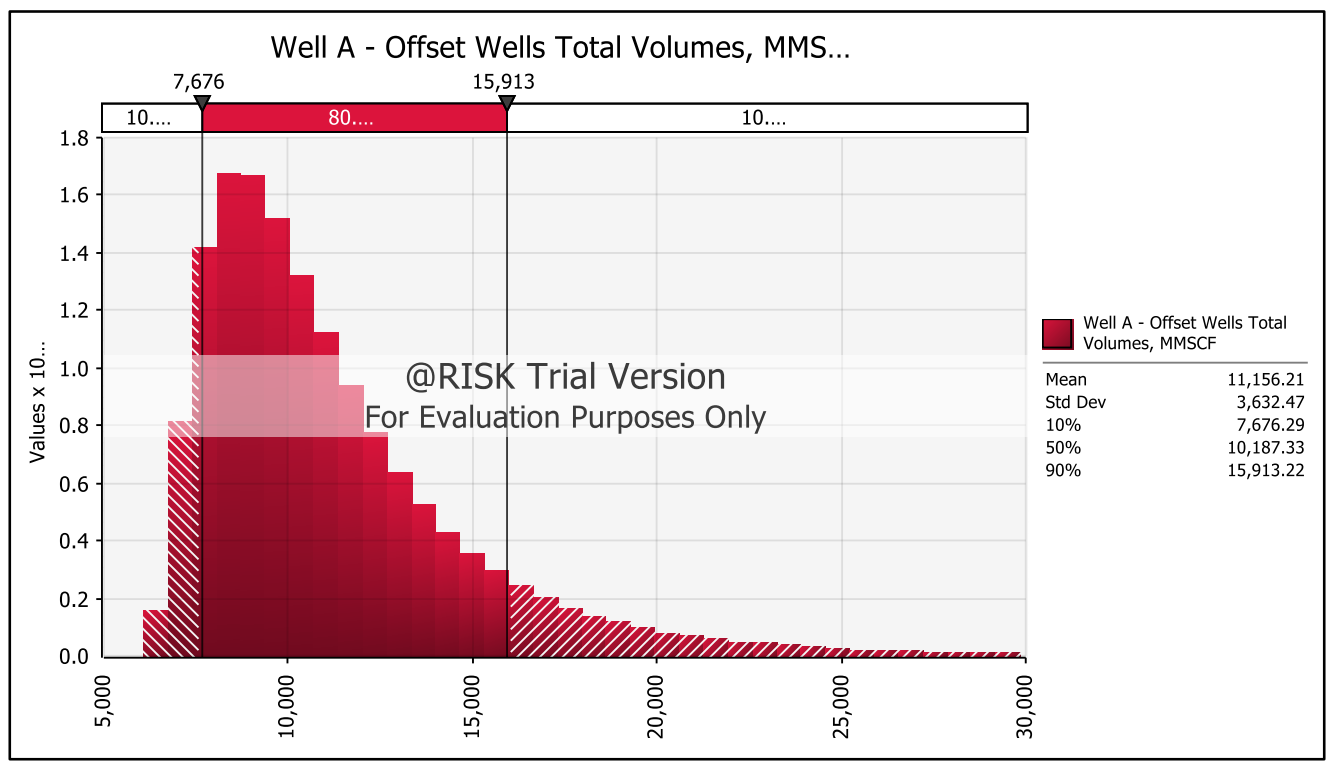

Fig. 11- Gas volumes distribution for 6 offset wells to well A 


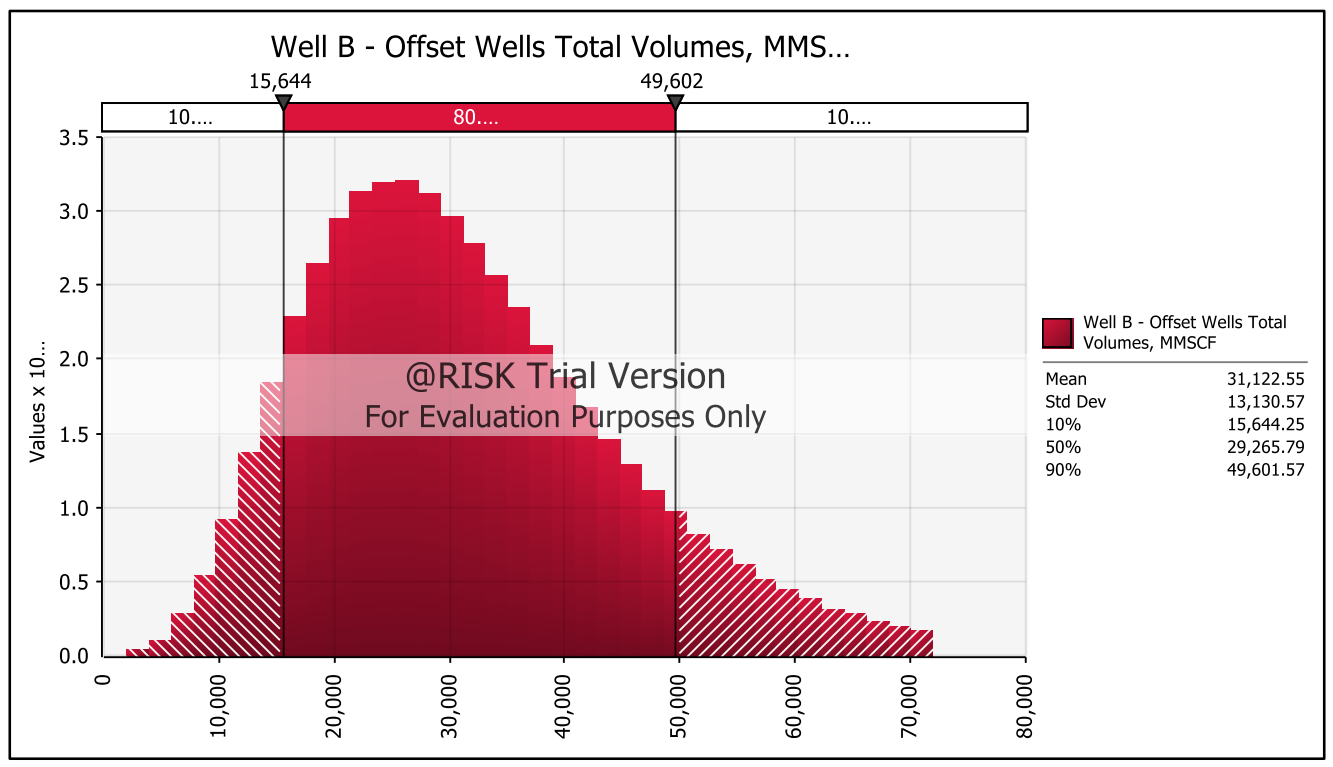

Fig. 12- Gas volumes distribution for 6 offset wells to well B

To classify the volumes above as reserves, they need to pass a commercial criterion; otherwise they would need to be classified as contingent resources. For this evaluation, a minimum $10 \%$ Internal Rate of Return (IRR) is required to consider the offset wells to be economic. Each individual-well type curve was evaluated with the assumptions listed in Table 10. For Well A only the P10 scenario meets the minimum IRR criteria, hence the volumes associated with the offset well locations are classified as contingent resources. For Well B, the P50 and P10 scenario result in attractive economics and hence the associated volumes are classified as reserves. Table 12 and Table 13 show the details of the economic evaluation results for each well. 
Table 12 - Economic evaluation for Well A type curve applicable to offset wells

\begin{tabular}{|c|c|c|c|c|}
\hline $\begin{array}{c}\text { Well } \\
\text { A }\end{array}$ & NPV@10\% & IRR & $\begin{array}{c}\text { Payout, } \\
\text { Months }\end{array}$ & $\begin{array}{c}\text { Volumes, } \\
\text { MMSCF }\end{array}$ \\
\hline P10 & $\$ 310,042$ & $11.1 \%$ & 81 & 2,547 \\
\hline P50 & $-\$ 1,222,757$ & $4.5 \%$ & 147 & 1,616 \\
\hline P90 & $-\$ 1,848,443$ & $-0.8 \%$ & NA & 1,216 \\
\hline
\end{tabular}

Table 13 - Economic evaluation for Well B type curve applicable to offset wells

\begin{tabular}{|c|c|c|c|c|}
\hline $\begin{array}{c}\text { Well } \\
\text { B }\end{array}$ & NPV@10\% & IRR & $\begin{array}{c}\text { Payout, } \\
\text { Months }\end{array}$ & $\begin{array}{c}\text { Volumes, } \\
\text { MMSCF }\end{array}$ \\
\hline P10 & $\$ 8,189,942$ & $25.8 \%$ & 42 & 8,128 \\
\hline P50 & $\$ 2,934,710$ & $17 \%$ & 59 & 4,679 \\
\hline P90 & $-\$ 150,835$ & $9.5 \%$ & 81 & 2,490 \\
\hline
\end{tabular}

The individual and total reserves and contingent resources results are shown in Table 14 and Table 15. The P90-P10 ranges obtained are smaller compared to those for the prospective resources. This is reasonable because these wells have been producing long enough (25 months well A, and 11 months well B) for the forecast to have a narrower range. 
Table 14- Individual and total reserves for applicable MX-EFS wells

\begin{tabular}{|c|c|c|c|c|c|c|}
\cline { 2 - 6 } \multicolumn{1}{c|}{} & \multicolumn{3}{c|}{ Oil, MSTB } & \multicolumn{3}{c|}{ Gas, MMSCF } \\
\hline Well & P90 & P50 & P10 & P90 & P50 & P10 \\
\hline A & & 586 & 1,007 & 1,987 \\
\hline B & & 2,145 & 4,449 & 8,079 \\
\cline { 1 - 6 } $\begin{array}{c}\text { Offsets to } \\
\text { Well B (6 } \\
\text { wells) }\end{array}$ & & - & - & $\mathbf{1 8 , 3 7 5}$ & $\mathbf{3 4 , 7 2 2}$ & $\mathbf{5 9 , 6 6 7}$ \\
\hline Totals & - & - & 15,644 & 29,266 & 49,601 \\
\hline
\end{tabular}

Table 15- Individual and total contingent resources for applicable MX-EFS wells

\begin{tabular}{|c|c|c|c|c|c|c|}
\cline { 2 - 7 } \multicolumn{1}{c|}{} & \multicolumn{3}{c|}{ Oil, MSTB } & \multicolumn{3}{c|}{ Gas, MMSCF } \\
\hline Well & P90 & P50 & P10 & P90 & P50 & P10 \\
\hline C & \multicolumn{3}{|c|}{} & 790 & 2,720 & 7,170 \\
\hline D & 14 & 64 & 228 & 60 & 420 & 2,900 \\
\hline $\begin{array}{c}\text { Offsets to } \\
\text { Well A } \\
\text { (6 wells) }\end{array}$ & \multicolumn{3}{|l|}{} & 7,676 & 10,187 & 15,913 \\
\hline Totals & $\mathbf{1 4}$ & $\mathbf{6 4}$ & $\mathbf{2 2 8}$ & $\mathbf{8 , 5 2 6}$ & $\mathbf{1 3 , 3 2 7}$ & $\mathbf{2 5 , 9 8 3}$ \\
\hline
\end{tabular}




\section{CONCLUSIONS}

Based on my study of the Mexican Eagle Ford shale, the following can be concluded:

- As of March 2013, the total prospective resources (P90-P50-P10) for the MXEFS are estimated to be 527-1,139-7,268 MMSTB of oil and 17-37-217 TSCF of gas. To my knowledge, this is the first oil estimate published for this formation in Mexico.

- The most attractive sectors based on total estimated resources as well as individual-well type curves are D1/D2 for oil (in the southeast of the Burgos Basin) and B1/B2/B3 and F1/F2 for gas (in the east and west of the Sabinas Basin).

- The main uncertainties that affect the estimates are the estimated analog type curves, the fluid type (for the South Mature US-EFS analog), and the well spacing. Further studies or analyses to better understand and reduce these uncertainties in each sector would increase the certainty of resources estimates.

- As of March 2013, estimated reserves (P90-P50-P10) associated with existing wells and corresponding offset well locations are 18,375-34,722-59,667 MMSCF for gas and zero for oil. Estimated contingent resources (P90-P50-P10) are 1464-228 MSTB of oil and 8,526-13,327-25,983MMSCF of gas. 


\subsection{Future work}

As is always the case with resource estimates, these are not static values and the inputs/assumptions of this study should be revised as more information becomes available with the area development or scientific/technological progress. The analog areas defined in this study can be refined as additional information/maps (e.g. permeability, pressure gradient, fluid types, natural fractures or mineral composition, completion techniques) become available both in the US and Mexico. Special attention should also be given to incorporate advances in the understanding of fluid-phase behavior and well spacing in shales, as these are topics not fully understood yet.

The estimates from this work can be used as a basis for project evaluation, selection and execution; the investors (either private, public or state owned) will have a clear view of the risk associated with the capital investment required to develop these resources. The results can also be the basis to determine the contract model (within Mexico's legal framework) that would maximize the value of the asset for Mexico, given the size and nature of the resource. 


\section{NOMENCLATURE}

$\begin{array}{ll}\text { EIA } & \text { Energy Information Agency } \\ \text { MCMC } & \text { Markov Chain Monte Carlo } \\ \text { EUR } & \text { Estimated ultimate recovery } \\ \text { MX-EFS } & \text { Eagle Ford shale in Mexico } \\ \text { PEMEX } & \text { Petróleos Mexicanos } \\ \text { US-EFS } & \text { Eagle Ford shale in the US } \\ \text { GOR } & \text { Gas/oil ratio } \\ \text { PRMS } & \text { Petroleum Resource Management System } \\ \text { TOC } & \text { Total organic content } \\ \text { BDF } & \text { Boundary dominated flow } \\ \text { MBM } & \text { Modified Bootstrap method } \\ \text { DCA } & \text { Decline-curve analysis } \\ \text { PDCA } & \text { Probabilistic decline-curve analysis } \\ \text { N240 } & \text { Prior distribution of cumulative production after 20 years } \\ \text { P10 } & \text { Value at confidence interval 10\% } \\ \text { P50 } & \text { Value at confidence interval 50\% } \\ \text { P90 } & \text { Value at confidence interval 90\% } \\ \text { IRR } & \text { Net present value at a 10\% discount rate } \\ \text { NPV@10\% } & \end{array}$




\section{REFERENCES}

Araujo, O., Lopez-Bonetti, E., and Sierra, J. 2012. Evaluating First Eagle Ford Shale Gas Well-Case History from Northern Mexico. Paper presented at the SPE Western Venezuela Section South American Oil and Gas Congress, Maracaibo, Venezuela. Copyright 2012, Society of Petroleum Engineers spe-163074-MS.

Arps, J.J. 1945. Analysis of Decline Curves. Trans. AIME 160: 228-247.

Baihly, J.D., Altman, R.M., Malpani, R. et al. 2010. Shale Gas Production Decline Trend Comparison over Time and Basins. Paper presented at the SPE Annual Technical Conference and Exhibition, Florence, Italy. Society of Petroleum Engineers SPE-135555-MS. DOI: 10.2118/135555-ms.

Benninger, W.A. and Caldwell, R.H. 1991. Estimating Decline Curves with Confidence. Oil \& Gas Journal 89 (105-105): 2.

Boulis, A., Jayakumar, R., Lalehrokh, F. et al. 2012. Improved Methodologies for More Accurate Shale Gas Assessments. Paper presented at the SPE Americas Unconventional Resources Conference, Pittsburgh, Pennsylvania USA. Society of Petroleum Engineers SPE-154981-MS. DOI: 10.2118/154981-ms.

Boyer, C., Kieschnick, J., Suarez-Rivera, R. et al. 2006. Producing Gas from Its Source. Oilfield Review (Autumn 2006): 36-49.

Cabrera, C., Soto, A., Maciel, M.A. et al. 2010a. Provincia Petrolera Burgos. PEMEX Exploracion y Produccion. 
Cabrera, C., Soto, A., Maciel, M.A. et al. 2010b. Provincia Petrolera Sabinas-BurroPicachos. PEMEX Exploracion y Produccion.

Caldwell, R.H. and Heather, D.I. 1991. How to Evaluate Hard-to-Evaluate Reserves (Includes Associated Papers 23545 and 23553 ). Journal of Petroleum Technology 43 (8): 998-1003. DOI: 10.2118/22025-pa

Cardneaux, A. 2012. Mapping of the Oil Window in the Eagle Ford Shale Play of Southwest Texas Using Thermal Modeling and Log Overlay Analysis. Master of Science Master of Science, Louisiana State University.

Chaudhary, A.S., Ehlig-Economides, C.A., and Wattenbarger, R.A. 2011. Shale Oil Production Performance from a Stimulated Reservoir Volume. Paper presented at the SPE Annual Technical Conference and Exhibition, Denver, Colorado, USA. Society of Petroleum Engineers SPE-147596-MS. DOI: 10.2118/147596-ms.

Cheng, Y., Wang, Y., McVay, D.A. et al. 2005. Practical Application of Probabilistic Approach to Estimate Reserves Using Production Decline Data. Paper presented at the SPE Annual Technical Conference and Exhibition, Dallas, Texas. Society of Petroleum Engineers SPE-95974-MS. DOI: 10.2118/95974-ms.

Clark, A.J., Lake, L.W., and Patzek, T.W. 2011. Production Forecasting with Logistic Growth Models. Paper presented at the SPE Annual Technical Conference and Exhibition, Denver, Colorado, USA. Society of Petroleum Engineers SPE144790-MS. DOI: 10.2118/144790-ms.

Dong, Z., Holditch, S.A., McVay, D. et al. 2011. Global Unconventional Gas Resource Assessments. Paper presented at the Canadian Unconventional Resources 
Conference, Alberta, Canada. Society of Petroleum Engineers SPE-148365-MS. DOI: $10.2118 / 148365-\mathrm{ms}$.

Duong, A.N. 2010. An Unconventional Rate Decline Approach for Tight and FractureDominated Gas Wells. Paper presented at the Canadian Unconventional Resources and International Petroleum Conference, Calgary, Alberta, Canada. Society of Petroleum Engineers SPE-137748-MS. DOI: 10.2118/137748-ms. Energy, U.S.D.o. 2011a. Review of Emerging Resources: U.S. Shale Gas and Shale Oil Plays, by EIA, U.S.E.I.A. Washington, DC.

Energy, U.S.D.o. 2011b. World Shale Gas Resources: An Initial Assessment of 14 Regions Outside the United States, by EIA, U.S.E.I.A. Washington,DC. Gong, X. 2013. Assessment of the Eagle Ford Shale Gas and Oil Resources. Doctor of Philosophy, Texas A\&M University.

Gong, X., Gonzalez, R.A., McVay, D. et al. 2011. Bayesian Probabilistic Decline Curve Analysis Quantifies Shale Gas Reserves Uncertainty. Paper presented at the Canadian Unconventional Resources Conference, Alberta, Canada. Society of Petroleum Engineers SPE-147588-MS. DOI: 10.2118/147588-ms.

Gonzalez, R. 2012. Using Decline Curve Analysis, Volumetric Analysis, and Bayesian Methodology to Quantify Uncertainty in Shale Gas Reserve Estimates. Master of Science, Texas A\&M University.

Ilk, D., Rushing, J.A., Perego, A.D. et al. 2008. Exponential Vs. Hyperbolic Decline in Tight Gas Sands - Understanding the Origin and Implications for Reserve Estimates Using Arps' Decline Curves. Paper presented at the SPE Annual 
Technical Conference and Exhibition, Denver, Colorado, USA. Society of Petroleum Engineers SPE-116731-MS. DOI: 10.2118/116731-ms.

Jochen, V.A. and Spivey, J.P. 1996. Probabilistic Reserves Estimation Using Decline Curve Analysis with the Bootstrap Method. Paper presented at the SPE Annual Technical Conference and Exhibition, Denver, Colorado. 1996 Copyright 1996, Society of Petroleum Engineers, Inc. 00036633. DOI: 10.2118/36633-ms.

Joshi, K.J. 2012. Comparison of Various Deterministic Forecasting Techniques in Shale Gas Reservoirs with Emphasis on the Duong Method. Master of Science, Texas A\&M University.

Kanfar, M. and Wattenbarger, R. 2012. Comparison of Empirical Decline Curve Methods for Shale Wells. Paper presented at the SPE Canadian Unconventional Resources Conference, Calgary, Alberta, Canada. Society of Petroleum Engineers SPE-162648-MS. DOI: 10.2118/162648-ms.

McVay, D.A. and Dossary, M. 2012. The Value of Assessing Uncertainty. Paper presented at the SPE Annual Technical Conference and Exhibition, San Antonio, Texas, USA. Society of Petroleum Engineers SPE-160189-MS. DOI: 10.2118/160189-ms.

Passey, Q.R., Bohacs, K., Esch, W.L. et al. 2010. From Oil-Prone Source Rock to GasProducing Shale Reservoir- Geologic and Petrophysical Characterization of Unconventional Shale-Gas Reservoirs. Paper presented at the International Oil and Gas Conference and Exhibition in China, Beijing, China. Society of Petroleum Engineers SPE-131350-MS. DOI: 10.2118/131350-ms. 
PEMEX, P.M. 2011. Estrategia De Shale Gas De Petroleos Mexicanos. Mexico DF: PEMEX.

Statton, J.C. 2012. Aplication of the Stretched Exponential Production Decline Model to Forecast Production in Shale Gas Reservoirs. Master of Science, Texas A\&M University.

Tellez-Aviles, M., Alvarado-Cespedes, A., Gonzalez-Garcia, A. et al. 2011. Evaluacion Geologico-Geoquimica De Las Lutitas Gasiferas Del Play K. Eagle Ford-Agua Nueva En La Plataforma De Tamaulipas Y Las Cuencas De Sabinas Y Burgos. In, ed. inicial, C.d.p.y.c.: PEMEX Exploracion y Produccion.

Tian, Y., Ayers, W., and McCain, W. 2013. The Eagle Ford Shale Play, South Texas:

Regional Variations in Fluid Types, Hydrocarbon Production and Reservoir Properties. Paper presented at the 6th International Petroleum Technology

Conference, Beijing, China. 2013, International Petroleum Technology

Conference IPTC-16808-MS. DOI: 10.2523/16808-ms.

Tian, Y., Ayers, W.B., and Jr., W.D.M. 2012. Regional Analysis of Stratigraphy, Reservoir Characteristics, and Fluid Phases in the Eagle Ford Shale, South Texas. Gulf Coast Association of Geological Societies Transactions 62: 471-483.

Valko, P.P. and Lee, W.J. 2010. A Better Way to Forecast Production from Unconventional Gas Wells. Paper presented at the SPE Annual Technical Conference and Exhibition, Florence, Italy. Society of Petroleum Engineers SPE-134231-MS. DOI: 10.2118/134231-ms. 